\title{
Regional geochemical variations in a metamorphosed black shale: a reconnaissance study of the Silurian Smalls Falls Formation, Maine, USA
}

\author{
John F. Slack ${ }^{1,2 *}$, M.R. VAn BaAlen ${ }^{3}$, And Douglas N. ReusCh ${ }^{4}$ \\ 1. U.S. Geological Survey (Emeritus), National Center, MS 954, Reston, Virginia 20192, USA \\ 2. Department of Earth Sciences, Memorial University of Newfoundland, St. John's, Newfoundland and Labrador A1B 3X5, Canada \\ 3. Department of Earth and Planetary Sciences, Harvard University, Cambridge, Massachusetts 02138, USA \\ 4. Department of Geology, University of Maine at Farmington, Farmington, Maine 04938, USA \\ *Corresponding author $<$ jfslack@usgs.gov $>$
}

Date received: 14 May 2020 gate accepted: 17 August 2020

\begin{abstract}
A reconnaissance geochemical study of 21 samples of sulphidic black phyllite and schist from the Silurian Smalls Falls Formation in Maine was undertaken in order to evaluate compositional changes during regional metamorphism. These samples represent variably metamorphosed black shale. Analyzed samples come from the chlorite zone in northern Maine and the biotite, garnet, and staurolite-andalusite zones in west-central Maine. Strata of the Smalls Falls Formation are distinctive in containing abundant pyrite and/or pyrrhotite (total $\mathrm{S}=$ 1.2-9.7 wt \%), but only minor organic matter or graphite (TOC $=0.43-1.85$ wt \%); TOC/S ratios are uniformly low (average $=0.37 \pm 0.22$ ). Median enrichment factors were calculated for each element by normalizing the concentration to $\mathrm{Ti}$ in each sample to the Ti-normalized median composition of global black shale. In the chlorite zone, moderate to large decreases in enrichment factors (-23.1 to $-49.8 \%$ ) are evident for $\mathrm{V}, \mathrm{Cr}, \mathrm{Cu}, \mathrm{Ni}, \mathrm{Zn}, \mathrm{Pb}, \mathrm{Sb}$, and $\mathrm{U}$, attributed here to various factors during sedimentation plus variable element mobility during diagenesis. With increasing metamorphic grade (biotite through staurolite-andalusite zones), systematic small to extreme decreases $(-14.5$ to $-99.0 \%)$ were found for $\mathrm{Ba}, \mathrm{Sb}, \mathrm{Au}$, and $\mathrm{U}$, together with less-systematic moderate to large decreases (-35.4 to $-61.1 \%)$ for $\mathrm{V}$ and As. Molybdenum shows an extreme decrease $(-94.7 \%)$ from the garnet to staurolite-andalusite zones. Excluding Ba, these results are interpreted to mainly reflect mobility of trace elements during pyrite recrystallization, and during the metamorphic transformations of organic matter to graphite and of pyrite to pyrrhotite. Moderate to large increases for $\mathrm{Rb}(+28.1$ to $+61.5 \%)$ and $\mathrm{Th}(+39.1$ to $+47.3 \%)$ from the biotite to staurolite-andalusite zones likely record the introduction of alkalis and mass loss, respectively, during metamorphism. Three samples from one site in the garnet zone differ in having anomalously high $\mathrm{Fe} / \mathrm{Al}$ and low $\mathrm{La} / \mathrm{Yb}$ ratios, attributed here to epigenetic formation of pyrite and related leaching of light rare earth elements during syn-metamorphic, channelized fluid flow.

Geologic and geochemical data indicate that strata of the Smalls Falls Formation were deposited during an interval of anoxia on the northwestern flank of the Central Maine Basin, for which detrital sources included an evolved continental arc. Onset of anoxia coincided with deposition of the Mayflower Hill Formation of the Vassalboro Group, on the basin's southeastern flank, related to emergence of the Brunswick subduction complex. We suggest that this emergence played a role in promoting both lateral and vertical circulation changes, nutrient loading, and deoxygenation through subsequent basin closure that culminated with Acadian deformation and metamorphism. Based on the relatively high contents of total sulphur present in our Smalls Falls samples, sediments in the Black Sea represent the only known plausible candidate among those in modern suboxic to euxinic basins.
\end{abstract}

\section{RÉSUMÉ}

Une étude géochimique de reconnaissance de 21 échantillons de schiste et de phyllite noirs sulfurés de la Formation silurienne de Smalls Falls dans le Maine a été réalisée pour évaluer les changements de la composition survenue durant le métamorphisme régional. Les échantillons en question représentent du schiste noir métamorphisé de façons variables. Les échantillons analysés proviennent de la zone de chlorite dans le nord du Maine et des zones de biotite, de grenat et de staurolite-andalousite dans le centre-ouest du Maine. Les strates de la Formation de Smalls Falls se distinguent par leur abondance en pyrite ou en pyrrhotite ( $\mathrm{S}$ total = 1,2 à 
$9,7 \%$ en poids), mais par une quantité modeste seulement de matière organique ou de graphite (COT $=0,43$ à $1,85 \%$ en poids); les ratios de COT/S sont uniformément bas (moyenne $=0,37 \pm 0,22$ ). On a calculé les facteurs d'enrichissement médians de chaque élément en normalisant la concentration en fonction du TI dans chaque échantillon d'après la composition médiane normalisée en TI de l'ensemble du schiste noir. Dans la zone de chlorite, des réductions moyennes à marquées des facteurs d’enrichissement (-23,1 à $-49,8 \%)$ sont évidentes dans le cas du V, du Cr, du Cu, du Ni, du Zn, du Pb, du Sb et de l'U; elles sont ici attribuées à divers facteurs ayant agi durant la sédimentation ainsi qu’à la mobilité variable des éléments durant la diagenèse. Au fur et à mesure que s'accentue l'intensité du métamorphisme (des zones de biotite à celles de staurolite-andalousite), on relève des réductions minimes à extrêmes systématiques $(-14,5$ à $-99,0 \%)$ du $\mathrm{Ba}, \mathrm{du} \mathrm{Sb}$, de l'Au et de l'U, de même que des réductions moyennes à marquées moins systématiques $(-35,4$ à $-61,1 \%)$ du V et de l'As. Le molybdène accuse une diminution extrême $(-94,7 \%)$ dans les zones de grenat passant à de la staurolite-andalousite. Sauf pour ce qui est $\mathrm{du} \mathrm{Ba}$, ces résultats sont principalement interprétés comme une réflexion de la mobilité des éléments traces durant la recristallisation de la pyrite et durant les transformations métamorphiques de la matière organique en graphite et en pyrite, puis en pyrrhotite. Les augmentations moyennes à prononcées du $\mathrm{Rb}(+28,1$ à $+61,5 \%)$ et du Th $(+39,1$ à $+47,3 \%)$ dans les zones de biotite devenant de la staurolite-andalousite témoignent vraisemblablement de l'introduction de minéraux alcalins et d'une perte massique, respectivement, durant le métamorphisme. Trois échantillons provenant d'un emplacement à l'intérieur de la zone de grenat se distinguent par des ratios anormalement élevés de $\mathrm{Fe} / \mathrm{Al}$ et faibles de $\mathrm{La} / \mathrm{Yb}$, attribués dans ce cas à la formation épigénétique de pyrite et au lessivage déléments de terres rares légers durant un écoulement des fluides canalisé, synmétamorphique. Des données géologiques et géochimiques révèlent que les strates de la Formation de Smalls Falls se sont déposées au cours d'un intervalle d'anoxie sur le flanc nord-ouest du bassin central du Maine, dont les sources détritiques ont compris un arc continental évolué. Le début de l’anoxie a coïncidé avec le dépôt de la Formation de Mayflower Hill du groupe de Vassalboro sur le flanc sud-est du bassin, conjointement à lémergence du complexe de subduction Brunswick. Nous croyons que cette émergence a contribué aux changements de la circulation latéraux et verticaux, à la charge en éléments nutritifs et à la désoxygénation par la fermeture subséquente du bassin, qui a culminé avec le métamorphisme et la déformation acadiens. À en juger d’après la teneur relativement élevée en soufre total présente dans nos échantillons de Smalls Falls, les sédiments de la mer Noire représentent le seul candidat plausible connu parmi ceux des bassins suboxiques à euxiniques modernes.

[Traduit par la redaction]

\section{INTRODUCTION}

The formation of organic-rich sedimentary rocks typically reflects several factors including high biological productivity, a slow sedimentation rate, and low redox states of bottom waters and pore fluids (Wignall 1994, and references therein). Many studies have evaluated compositional changes in organic-poor shale as a function of diagenesis and metamorphism (e.g., Ague 1991, 1994a; Land et al. 1997; Milliken 2003; Masters and Ague 2005; Merriman et al. 2009), and several have discussed diagenetic effects in organic-rich shale (Hannigan and Basu 1998; Lev et al. 2008; Abanda and Hannigan 2006; Yang et al. 2018a), but to our knowledge no publications exist that evaluate the influence of metamorphism on the full spectrum of inorganic components in black shales.

This report presents whole-rock analyses for major elements, trace elements, and rare earth elements (REE) in a reconnaissance study (21 samples) of variably sulphidic black phyllite and schist from the Silurian Smalls Falls Formation in northern and western Maine. These samples represent variably metamorphosed black shale. The geochemical data reported here are used as a basis for better understanding the mineralogical and compositional effects of Silurian diagenesis and Devonian regional metamorphism. We also present trace element data bearing on the provenance of the original sediments of this formation and related tectonic implications.
Early geochemical studies of the Smalls Falls Formation were restricted to analysis of only a few samples (Cullers et al. 1997). Two field trip guidebooks by Guidotti and Van Baalen (2001) and Van Baalen (2006) presented results for a limited number of trace elements, together with a discussion of environmental issues focused on arsenic. Our paper reports data for a much larger suite of elements with greater analytical precision, and supersedes the bulk compositions reported in these two guidebooks as well as those in the guidebook chapter by Van Baalen et al. (2017).

\section{GEOLOGIC SETTING}

The Smalls Falls Formation forms part of the Central Maine Basin (CMB; Fig. 1) that contains marine metasedimentary rocks of Late Ordovician to Early Devonian age (Osberg et al. 1985; Ludman et al. 2017). On its northwest flank, strata of the CMB conformably overlie Ordovician and Cambrian marine sedimentary and volcanic rocks of the Bronson Hill belt (Moench 2006). Relationships along the southeastern margin of the $\mathrm{CMB}$ are diverse, ranging from fault contacts in southern Maine (e.g., Liberty-Orrington belt) to a Salinic (Silurian) unconformity in New Brunswick (Ludman et al. 2017). Paleocurrent data and stratigraphic relationships suggest that the $\mathrm{CMB}$ received sediment from the northwest during the Early Silurian, and subsequently also from the southeast (Bradley and Hanson 2002). 


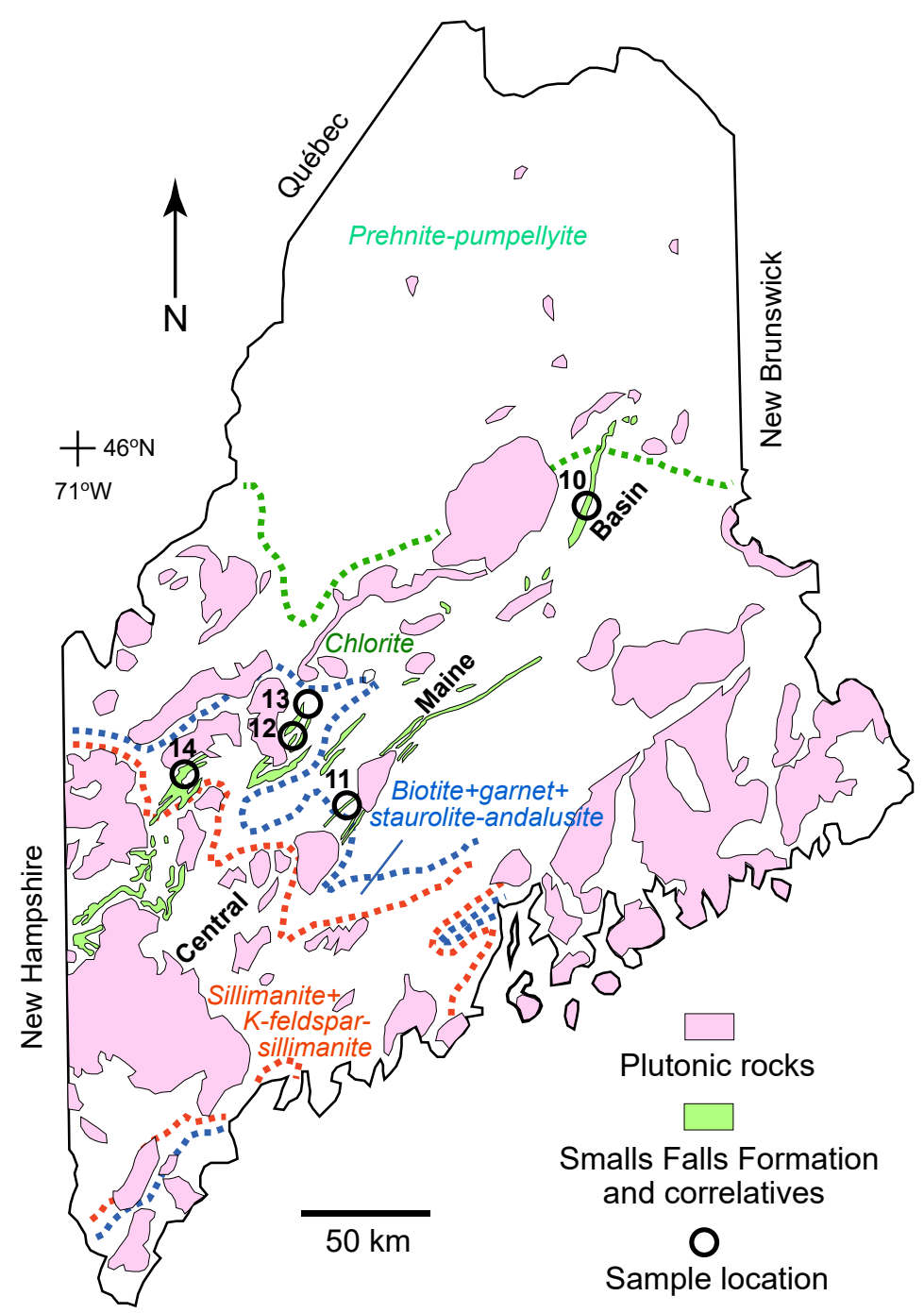

Figure 1. Simplified geological map of Maine showing distribution of the Smalls Falls Formation and correlatives, regional metamorphic zones, and sample locations. Plutonic rocks consist of granite with subordinate gabbro, chiefly of Ordovician and Devonian age. Uncolored areas are mainly lower to middle Paleozoic metasedimentary and metavolcanic rocks. Geology and metamorphic zones adapted from Osberg et al. (1985). Regional geology for location 10 is available in Roy (1981) and Roy et al. (1983); for locations 11-14, see Moench and Pankiwskyj (1988).

Strata of the Smalls Falls Formation and correlatives extend ca. $600 \mathrm{~km}$ from northern Maine southward through New Hampshire and Massachusetts. In west-central Maine, the Smalls Falls Formation overlies, with sharp contact, quartz-rich turbidites of the Silurian Perry Mountain Formation and sandstone and conglomerate of the underlying Rangeley Formation (Boone et al. 1970, Boone 1973; Moench 2006). The Smalls Falls underlies calcareous turbidites of the Silurian-Devonian Madrid Formation and predominantly siliciclastic strata of the Devonian Seboomook Group. In northern and northeastern Maine, the correlative upper slate member ("sulfidic phyllite") of the Allsbury Formation overlies phyllite, siltstone, and sandstone of the lower part of the Allsbury, and underlies quartzo-feldspathic greywacke and minor non-graphitic slate/phyllite of the Silurian Lawler Ridge Formation correlated with the Madrid Formation, and turbidites of the Devonian Seboomook Group (Roy et al. 1983). According to Ludman et al. (2017), strata of the Smalls Falls Formation record the last pre-orogenic sedimentation prior to development of the Acadian foreland basin during the early Emsian (e.g., Bradley et al. 2000).

The Smalls Falls Formation was assigned by Moench et al. (1995) to a Ludlovian (Late Silurian) age based on rare graptolites in the correlated Parkman Hill Formation several tens of kilometres east of the Smalls Falls type locality. More recently, Bradley and O'Sullivan (2016) reported a detrital zircon date of $409 \mathrm{Ma}$ for the youngest age population in the Smalls Falls Formation, suggesting a maximum depositional age of Pragian (Early Devonian). However, this maximum age may underestimate the true depositional age because of possible inadvertent measurement of high- $U$ metamorphic rims on the zircon grains, as well as other geologic factors 
(see Bradley and O'Sullivan 2016). For the purposes of this report, we assume that the Smalls Falls Formation is Ludlovian pending more detailed studies.

Thicknesses of Smalls Falls strata and correlatives vary from ca. $115 \mathrm{~m}$ in the northeast (Roy et al. 1983), to ca. 480 $\mathrm{m}$ in the central part of the study area (Boone 1973), to approximately $1150 \mathrm{~m}$ in western Maine (Moench 2006). The formation thins southeastward from its type locality on the northwest flank of the Bear Hill syncline across the Strickland Hill anticline to the Currier Hill syncline (Moench and Pankiwskyj 1988). Farther southeast, the Smalls Falls is absent, and instead sandstones of the time-equivalent Mayflower Hill Formation conformably overlie the Wenlock Waterville Formation in an overall coarsening-upwards sequence (Marvinney et al. 2010). In addition to black phyllite or schist, interbeds of sulphidic metasiltstone or quartzite up to several centimeters thick are common in many exposures. In the type area at Smalls Falls, quartzite-rich turbidites typically display grading and cross laminations; feldspathic and calcareous metasiltstone (or calc-silicate) beds are common in the upper part of the formation (Moench 2006). No evidence was discovered in our sampled outcrops of veins or of other epigenetic hydrothermal products, although surface oxidation in many places prevents a thorough evaluation of this possibility. Importantly, on the scale of hand specimens (and drill cores), no quartz- or sulphide-rich veins were found.

\section{METAMORPHIC FRAMEWORK}

Metamorphic zones vary greatly in Maine (Fig. 1). In northernmost exposures of the Smalls Falls Formation, sedimentary strata are at prehnite-pumpellyite grade (Richter and Roy 1974). Progressively to the southwest, the metamorphic grade increases through lower greenschist (chlorite, biotite), to upper greenschist (garnet), middle amphibolite (staurolite-andalusite), and upper amphibolite (sillimanite and sillimanite-K-feldspar). Regional metamorphic assemblages of the greenschist-facies event (M1) were overprinted by assemblages produced during three later events that developed within the thermal regimes of high temperature-low pressure (HT-LP) associated with intrusion of granitic and subordinate gabbroic plutons of Devonian (M2, M3) and Carboniferous (M4) age (Guidotti and Holdaway 1993; Guidotti et al. 1996; Guidotti and Johnson 2002). In western Maine, proximity and annular distribution of the biotite, garnet, staurolite-andalusite, sillimanite, and sillimanite-K-feldspar zones around plutons (Boone 1973; Guidotti 1974; Moench and Pankiwskyj 1988; Guidotti et al. 1996) suggests a genetic link, as proposed also for the type area of Buchan HT-LP metamorphism in northeastern Scotland (e.g., Lyubetskaya and Ague 2010).

Iron-rich silicate and oxide minerals including chloritoid, garnet, staurolite, and ilmenite are rare to absent in sulphide-rich samples from the Smalls Falls Formation owing to sequestering of $\mathrm{Fe}^{2+}$ via metamorphic sulphidation reactions during the formation of pyrrhotite from pyrite. Instead, among silicate minerals, Mg-rich chlorite, phlogopite, and cordierite predominate, and rutile among oxide minerals, depending on metamorphic grade (Henry 1981; Guidotti et al. 1977; Guidotti and Van Baalen 2001; Van Baalen 2006).

\section{METHODS}

Samples were collected from outcrops and road cuts mainly with a small diamond drill in order to obtain unweathered rock. Studied drill cores, $2.5 \mathrm{~cm}$ in diameter, are mostly 8 to $12 \mathrm{~cm}$ long. Sample locations and descriptions are given in Table 1. Geological settings for the sampled outcrops are available in Roy et al. (1983) for the chlorite zone, Ludman (1977) for the biotite zone, Boone (1973) for the garnet zone, and Guidotti and Van Baalen (2001) for the staurolite-andalusite zone. Samples analyzed in our study come from the M1 chlorite zone, and the M2 biotite, garnet, and staurolite-andalusite zones (Fig. 1). In addition to these four metamorphic zones, attempts were made to collect samples of sulphide-rich black shale from the prehnite-pumpellyite zone and sulphide-rich schist from the sillimanite and sillimanite + K-feldspar zones, but without success. Sampling was focused on quartz-poor intervals, but in some cases it was not possible to avoid the inclusion of thin $(<5 \mathrm{~mm})$ laminae of metasiltstone or quartzite in the samples.

Major elements were analyzed by X-ray fluorescence at AGAT Laboratories. Total sulphur was determined by an automated LECO analyzer and carbonate carbon by coulometric titration, both at AGAT Laboratories. Trace elements and rare earth elements (REE) were determined at SGS Laboratories, the former by Inductively Coupled Plasma-Atomic Emission Spectrometry (ICP-AES) and the latter by Inductively Coupled Plasma-Mass Spectrometry (ICP-MS) after sodium peroxide fusion. Contents of $\mathrm{Au}, \mathrm{Pd}$, and $\mathrm{Pt}$ were obtained by fire assay. Four USGS rock standards including shales SCo-1, SBC-1, and SGR-1, and black shale SDO-1, were run to monitor accuracy and precision. Details of method descriptions and analytical performance are presented in Granitto et al. (2017). Complete analyses and related element ratios are reported in Tables $\mathrm{A} 1$ and $\mathrm{A} 2$ in the Appendix.

Mineralogical studies were carried out at the U.S. Geological Survey in Reston, Virginia, using standard petrography (transmitted and reflected light microscopy) and scanning electron microscopy (SEM). Imaging and identification of fine-grained minerals were done with a Hitachi SU-5000 field-emission SEM (15 kV, spot intensity 30, working distance $10 \mathrm{~mm}$ ), coupled to an EDAX Octane Plus Silicon Drift Detector for compositional analysis via Energy Dispersive Spectrometry (EDS). 
Table 1. Locations and descriptions of analyzed samples from the Small Falls Formation in Maine.

\begin{tabular}{|c|c|c|c|c|c|}
\hline Location $^{*}$ & $\begin{array}{l}\text { Sample } \\
\text { number }\end{array}$ & $\begin{array}{c}\text { Latitude and } \\
\text { longitude }\end{array}$ & $\begin{array}{c}\text { Metamorphic } \\
\text { grade }\end{array}$ & Description & Notes \\
\hline 10 & JS-13-10A & $45^{\circ} 45^{\prime} 05^{\prime \prime} \mathrm{N}, 68^{\circ} 27^{\prime} 19^{\prime \prime} \mathrm{W}$ & Chlorite & Black pyritic phyllite; orange carb & Strat middle of ocp \\
\hline 10 & JS-13-10B & $45^{\circ} 45^{\prime} 05^{\prime \prime} \mathrm{N}, 68^{\circ} 27^{\prime} 19^{\prime \prime} \mathrm{W}$ & Chlorite & Black pyritic phyllite; slt laminae & $2 \mathrm{~m}$ strat below $\mathrm{A}$ \\
\hline 10 & JS-13-10C & $45^{\circ} 45^{\prime} 05^{\prime \prime} \mathrm{N}, 68^{\circ} 27^{\prime} 19^{\prime \prime} \mathrm{W}$ & Chlorite & Black pyritic phyllite; slt laminae & $2 \mathrm{~m}$ strat below B \\
\hline 10 & JS-13-10D & $45^{\circ} 45^{\prime} 05^{\prime \prime} \mathrm{N}, 68^{\circ} 27^{\prime} 19^{\prime \prime} \mathrm{W}$ & Chlorite & Dark grey pyritic phyllite; slt laminae & $2 \mathrm{~m}$ strat below first ss bed \\
\hline 10 & JS-13-10E & $45^{\circ} 45^{\prime} 05^{\prime \prime} \mathrm{N}, 68^{\circ} 27^{\prime} 19^{\prime \prime} \mathrm{W}$ & Chlorite & Dark grey pyritic phyllite & $2 \mathrm{~m}$ strat above first ss bed \\
\hline 11 & JS-13-11A & $44^{\circ} 46^{\prime} 17^{\prime \prime} \mathrm{N}, 69^{\circ} 42^{\prime} 31^{\prime \prime} \mathrm{W}$ & Biotite & Dark grey pyritic schist & Strat highest exposure \\
\hline 11 & JS-13-11B & $44^{\circ} 46^{\prime} 17^{\prime \prime} \mathrm{N}, 69^{\circ} 42^{\prime} 31^{\prime \prime} \mathrm{W}$ & Biotite & Dark grey pyritic schist & $0.5 \mathrm{~m}$ strat below A \\
\hline 11 & JS-13-11C & $44^{\circ} 46^{\prime} 17^{\prime \prime} \mathrm{N}, 69^{\circ} 42^{\prime} 31^{\prime \prime} \mathrm{W}$ & Biotite & Dark grey pyritic schist; slt laminae & $1 \mathrm{~m}$ strat below B \\
\hline 11 & JS-13-11D & $44^{\circ} 46^{\prime} 17^{\prime \prime} \mathrm{N}, 69^{\circ} 42^{\prime} 31^{\prime \prime} \mathrm{W}$ & Biotite & Dark grey pyritic schist; slt laminae & $0.5 \mathrm{~m}$ strat below $\mathrm{C}$ \\
\hline 11 & JS-13-11E & $44^{\circ} 46^{\prime} 17^{\prime \prime} \mathrm{N}, 69^{\circ} 42^{\prime} 31^{\prime \prime} \mathrm{W}$ & Biotite & Dark grey pyritic schist & $1 \mathrm{~m}$ strat below $\mathrm{D}$ \\
\hline 11 & JS-13-11F & $44^{\circ} 46^{\prime} 17^{\prime \prime} \mathrm{N}, 69^{\circ} 42^{\prime} 31^{\prime \prime} \mathrm{W}$ & Biotite & Dark grey pyritic schist & $0.5 \mathrm{~m}$ strat below $\mathrm{E}$ \\
\hline 11 & JS-13-11G & $44^{\circ} 46^{\prime} 17^{\prime \prime} \mathrm{N}, 69^{\circ} 42^{\prime} 31^{\prime \prime} \mathrm{W}$ & Biotite & Dark grey pyritic schist & $0.1 \mathrm{~m}$ strat below $\mathrm{E}$ \\
\hline 12 & JS-13-12A & $45^{\circ} 03^{\prime} 07^{\prime \prime} \mathrm{N}, 69^{\circ} 53^{\prime} 13^{\prime \prime} \mathrm{W}$ & Garnet & Dark grey pyrite-rich schist & South end of ocp \\
\hline 12 & JS-13-12B & $45^{\circ} 03^{\prime} 07^{\prime \prime} \mathrm{N}, 69^{\circ} 53^{\prime} 13^{\prime \prime} \mathrm{W}$ & Garnet & Dark grey pyrite-rich schist & ca. $8 \mathrm{~m}$ strat below A \\
\hline 12 & JS-13-12C & $45^{\circ} 03^{\prime} 07^{\prime \prime} \mathrm{N}, 69^{\circ} 53^{\prime} 13^{\prime \prime} \mathrm{W}$ & Garnet & Dark grey pyrite-rich schist & ca. $8 \mathrm{~m}$ strat below B \\
\hline 13 & JS-13-13B & $45^{\circ} 04^{\prime} 16^{\prime \prime} \mathrm{N}, 69^{\circ} 54^{\prime} 53^{\prime \prime} \mathrm{W}$ & Garnet & Dark grey pyrite-rich schist & Locally abundant Py \\
\hline 14 & JS-13-14A & $44^{\circ} 51^{\prime} 33^{\prime \prime} \mathrm{N}, 70^{\circ} 31^{\prime} 02^{\prime \prime} \mathrm{W}$ & Staurolite-andalusite & Dark grey pyrrhotite-rich schist & Strat upper part of ocp \\
\hline 14 & JS-13-14B & $44^{\circ} 51^{\prime} 33^{\prime \prime} \mathrm{N}, 70^{\circ} 31^{\prime} 02^{\prime \prime} \mathrm{W}$ & Staurolite-andalusite & Dark grey pyrrhotite-rich schist & ca. $7 \mathrm{~m}$ strat below A \\
\hline 14 & JS-13-14C & $44^{\circ} 51^{\prime} 34^{\prime \prime} \mathrm{N}, 70^{\circ} 31^{\prime} 04^{\prime \prime} \mathrm{W}$ & Staurolite-andalusite & Dark grey pyrrhotite-rich schist & ca. $30 \mathrm{~m}$ strat below B \\
\hline 14 & JS-13-14D & $44^{\circ} 51^{\prime} 48^{\prime \prime} \mathrm{N}, 70^{\circ} 31^{\prime} 14^{\prime \prime} \mathrm{W}$ & Staurolite-andalusite & Dark grey pyrrhotite-rich schist & Abundant coarse andalusite \\
\hline 14 & JS-13-14E & $44^{\circ} 51^{\prime} 48^{\prime \prime} \mathrm{N}, 70^{\circ} 31^{\prime} 15^{\prime \prime} \mathrm{W}$ & Staurolite-andalusite & Dark grey pyrrhotite-rich schist & Abundant coarse andalusite \\
\hline
\end{tabular}

${ }^{*}$ Geographic locations: 10, Benedicta, outcrops on W side of southbound Interstate I-95; 11, Skowhegan, outcrop along N shore of Kennebec River $\sim 100$ m south of Rte 2; 12, Bingham, outcrop at W end of Bridge Street on W side of Kennebec River; 13, Outcrop along Pleasant Ridge Rd north of Wyman Dam; 14, Roadcuts along Rte $4 \mathrm{~N}$ of type area at Smalls Falls.

Abbreviations: carb, carbonate; ocp, outcrop; Po, pyrrhotite; Py, pyrite; ss, metasandstone; slt, metasiltstone; strat, stratigraphic or stratigraphically.

\section{RESULTS}

\section{Mineralogy}

Mineral assemblages vary partly as a function of metamorphic grade. In the chlorite zone, assemblages comprise quartz, muscovite, and chlorite with minor plagioclase and pyrite, and sparse $\mathrm{Fe}-\mathrm{Mg}$ carbonate and apatite. Carbon phases, which include organic matter (OM) and graphite, are dispersed among other constituents. Pyrite typically forms subhedral and euhedral grains mainly in silty laminae (Fig. 2a). Less common is framboidal pyrite, uniformly less than $7 \mu \mathrm{m}$ in diameter, occurring preferentially in a local matrix of Fe-Mg carbonate and albite, or quartz (Fig. 3a, b). Monazite, ilmenite, and zircon are trace constituents.

Samples from the biotite zone are also dominated by quartz and muscovite, with minor plagioclase and pyrite, local phlogopite, and sparse apatite and ilmenite (Fig. 2b). Carbonate is nearly absent and carbon phases are less abundant than in samples from the chlorite zone. Significantly, pyrite occurs only as subhedral or euhedral crystals, locally with inclusions of chalcopyrite or galena. Trace minerals include monazite and zircon.

Garnet-zone samples comprise quartz and muscovite and, with one exception, lack carbonate. Garnet is absent from sulphide-rich samples. Plagioclase is present in a single sample. Apatite, ilmenite, and carbon phases are sparse constituents; monazite and zircon occur in trace amounts. Pyrite forms anhedral grains aligned in the dominant foliation (Fig. 2c), and subhedral to euhedral crystals with large pyrrhotite and small sphalerite inclusions (Fig. 2d).

Samples from the staurolite-andalusite zone mostly contain quartz and muscovite with minor phlogopite and coarse-grained (up to several $\mathrm{cm}$ ) iron sulphides, and sparse plagioclase. Cordierite and andalusite are present locally. Carbon phases are negligible; apatite and rutile are rare. Monazite and zircon are trace constituents. Pyrrhotite predominates over pyrite, the former locally containing inclusions and veinlets of chalcopyrite (Fig. 2e), and inclusions of galena (Fig. 2f) and/or sphalerite. Staurolite is absent in sulphide-rich samples.

Yttrobetafite- $(\mathrm{Y}) \quad\left[(\mathrm{Y}, \mathrm{U}, \mathrm{Ce})_{2}\left(\mathrm{Ti}, \mathrm{Nb}, \mathrm{Ta}_{2} \mathrm{O}_{6}(\mathrm{OH})\right] \quad\right.$ was discovered in one of our sampled outcrops by Van Baalen et al. (2005). Although this mineral was not found during our reconnaissance SEM work, it is likely present in many samples, based on whole-rock geochemical data that show a strong positive correlation $\left(\mathrm{R}^{2}=0.73\right)$ of $\mathrm{Y}+\mathrm{Ce}+\mathrm{U}$ with $\mathrm{Ti}+\mathrm{Nb}+\mathrm{Ta}$. 

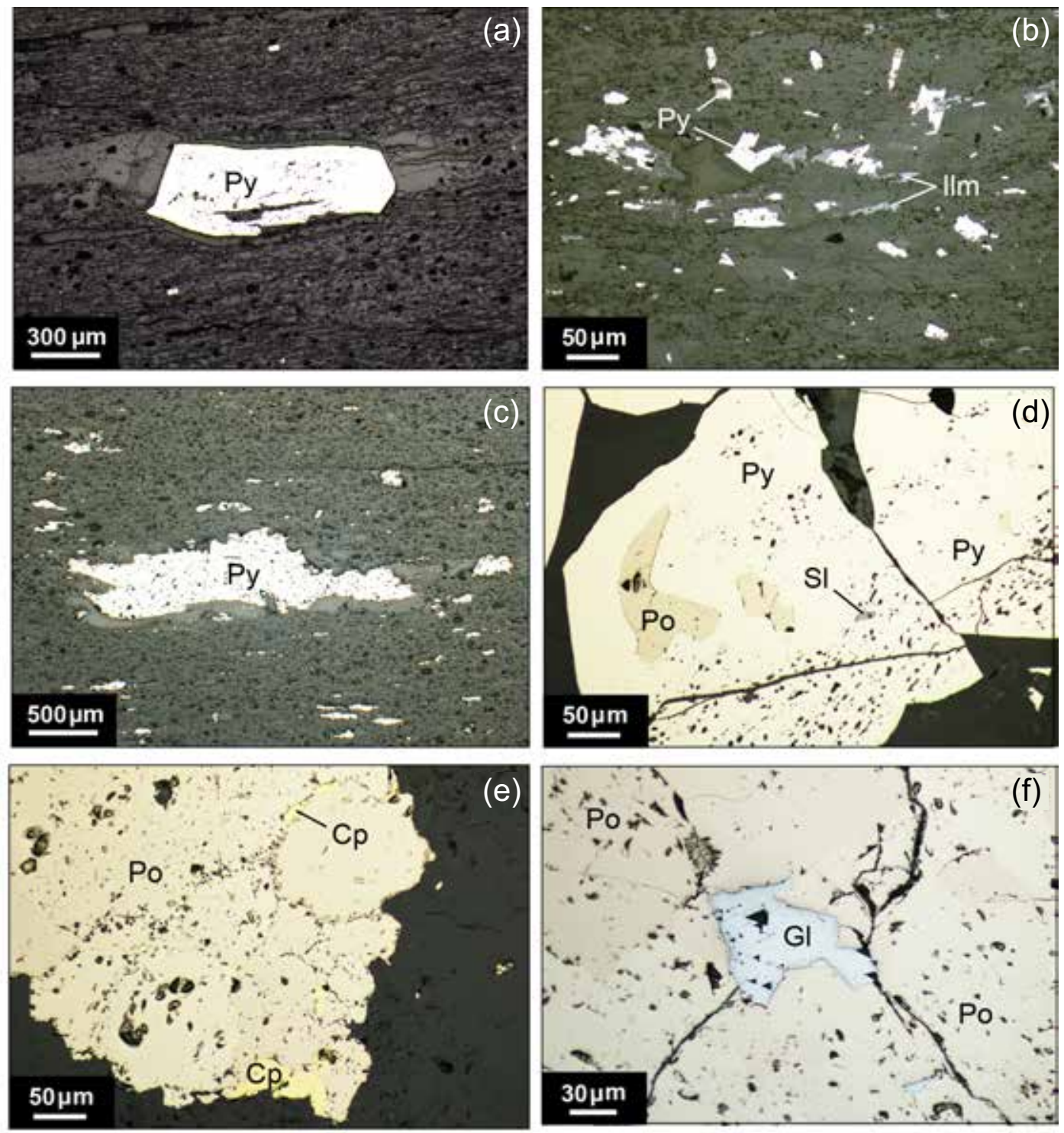

Figure 2. Photomicrographs in reflected light of analyzed samples from the Smalls Falls Formation. (a), Subhedral pyrite with silicate inclusions and thin oxidized rim, in matrix of silicates, minor carbonate, and trace sulphide; sample JS-1310B (chlorite zone). (b), Euhedral pyrite in matrix of silicates and minor carbonate with sparse ilmenite; sample JS-13-11B (biotite zone). (c), Anhedral foliated pyrite in silicate matrix; sample JS-13-12A (garnet zone). (d), Large pyrrhotite and small sphalerite inclusions in subhedral pyrite; sample JS-13-12B (garnet zone). (e), Anhedral pyrrhotite with rims and veinlets of chalcopyrite; sample JS-13-14A (staurolite-andalusite zone). (f), Anhedral pyrrhotite with inclusion of galena; sample JS-13-14B (staurolite-andalusite zone). Abbreviations: Cp, chalcopyrite; Gl, galena; Ilm, ilmenite; Po, pyrrhotite; Py, pyrite; Sl, sphalerite.

\section{Geochemical data}

Whole-rock analyses for major, minor, and trace elements (including REE) were acquired on 21 samples of black phyllite and schist from the Smalls Falls Formation. Significant variations among major elements are shown by $\mathrm{SiO}_{2}(54.6-$ $72.0 \mathrm{wt} \%), \mathrm{Al}_{2} \mathrm{O}_{3}(7.15-20.2 \mathrm{wt} \%), \mathrm{Fe}_{2} \mathrm{O}_{3}^{\mathrm{T}}(2.30-12.7 \mathrm{wt} \%)$, $\mathrm{MgO}\left(0.93-3.53\right.$ wt \%), $\mathrm{CaO}\left(0.43-3.75\right.$ wt \%), $\mathrm{Na}_{2} \mathrm{O}(0.43-$ $1.82 \mathrm{wt} \%)$, and $\mathrm{K}_{2} \mathrm{O}(1.41-4.34 \mathrm{wt} \%)$. Contents of $\mathrm{MnO}$ and $\mathrm{P}_{2} \mathrm{O}_{5}$ are low $\left(<0.32\right.$ and $<0.20 \mathrm{wt} \%$, respectively). $\mathrm{TiO}_{2}$ varies from 0.35 to $0.97 \mathrm{wt} \%$. TOC values (organic + graphitic
C) are 0.43 to $1.85 \mathrm{wt} \%$; most samples have below $1.0 \mathrm{wt} \%$. Significantly, total sulphur is generally high (1.2-9.7 wt \%); these total S contents wholly reflect sulphide sulphur (pyrite \pm pyrrhotite \pm chalcopyrite \pm sphalerite \pm galena), given the absence of barite or appreciable amounts of other potentially sulphur-rich minerals such as apatite. Concentrations of base and related transition metals include $\mathrm{Co}=12.6$ to 38.6 ppm, $\mathrm{Cu}=24$ to $64 \mathrm{ppm}, \mathrm{Ni}=34$ to $82 \mathrm{ppm}, \mathrm{Pb}=11$ to 34 $\mathrm{ppm}$, and $\mathrm{Zn}=6$ to $132 \mathrm{ppm}$. Contents of $\mathrm{Cr}$ and $\mathrm{V}$ are $\leq 100$ and $\leq 217 \mathrm{ppm}$, respectively. Data for high field strength elements show the following ranges: $\mathrm{Nb}$ (7-18 ppm), 

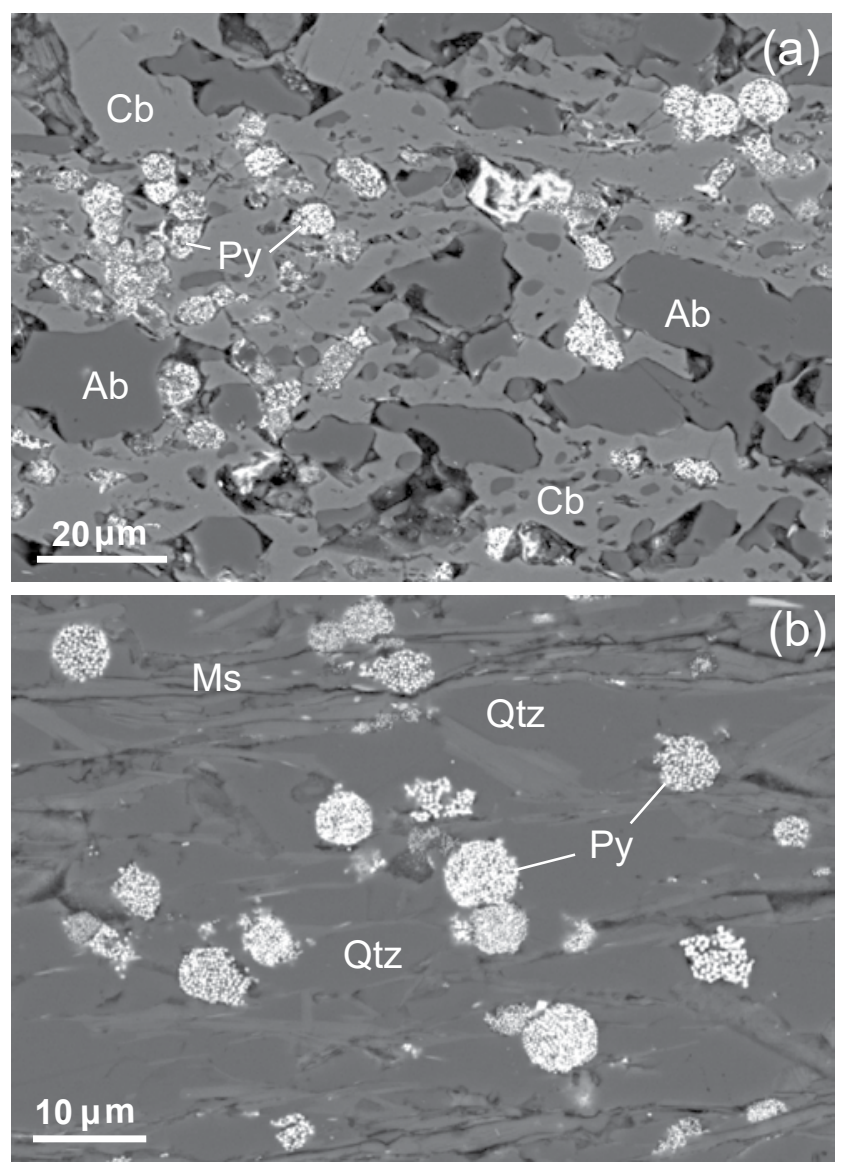

Figure 3. SEM-BSE images of framboidal pyrite in chlorite-grade rock from the Smalls Falls Formation. (a), Small framboids in matrix of Fe-Mg carbonate and albite; sample JS-13-10B. (b), Small framboids in matrix of albite and muscovite; sample JS-13-10B. Note diameters of framboidal pyrite grains are all $<8 \mu \mathrm{m}$ (see text). Abbreviations: $\mathrm{Ab}$, albite; $\mathrm{Cb}$, carbonate; Ms, muscovite; Qtz, quartz; Py, pyrite.

Th (4.20-17.4 ppm), and $\mathrm{Zr}$ (97.3-331 ppm). Uranium concentrations vary from 2.87 to $15.2 \mathrm{ppm}$. REE contents vary widely (e.g., $\mathrm{La}=11.7-48.9 \mathrm{ppm} ; \mathrm{Yb}=1.50-5.30$ ppm). Similar ranges in concentration were reported by Van Baalen (2006) for a different suite of six samples from the Smalls Falls Formation, from different metamorphic grades, including for $\mathrm{Ni}(<100 \mathrm{ppm}), \mathrm{Pb}(<21 \mathrm{ppm}), \mathrm{Cr}(<155 \mathrm{ppm})$, $\mathrm{V}(<167 \mathrm{ppm})$, and $\mathrm{U}(\leq 10 \mathrm{ppm})$.

\section{Carbon-sulphur-molybdenum relationships}

Figure 4a shows a plot of whole-rock data for total TOC vs total sulphur in which TOC includes both carbonaceous and graphitic carbon. Noteworthy are the uniformly low TOC contents (most $<1.0 \mathrm{wt} \%$ ) and generally high total S values (most $\sim 2-4$ wt \%; up to 9.7 wt \%). Ratios of TOC/ total $S$ are all less than 1.0, averaging $0.37 \pm 0.22$. Data for the Smalls Falls samples differ greatly from those for modern marine sediments, euxinic Black Sea sediments, and sulphide-rich black shales of the Upper Devonian-Lower Mississippian Bakken Formation (Montana) and the Jurassic Jet Rock Member of the Whitby Mudstone Formation (U.K.). To our knowledge, no modern or ancient unmineralized black shales or their lithologic equivalents have such low TOC yet high total S contents above ca. $2 \mathrm{wt} \%$.

A plot of TOC vs Mo (Fig. 4b) shows a similar trend in which uniformly low TOC contents are paired by relatively low Mo ( $\leq 61 \mathrm{ppm})$. Compared to modern anoxic to euxinic settings, data for the Smalls Falls samples display much lower Mo/TOC ratios. Moreover, none of our samples has Mo contents at or above $100 \mathrm{ppm}$, which is the inferred lower limit for persistent euxinic (sulphidic) conditions during deposition (Scott and Lyons 2012).

Figure $4 \mathrm{c}$ is a plot of total $\mathrm{S}$ vs Mo. These data reinforce the key point that despite high $S$ contents that approach 10 wt \%, Mo concentrations are uniformly low. For comparison, most analyses of the locally pyrite-rich Bakken Formation (Scott et al. 2017b) show higher Mo at a given total S content than our samples from the Smalls Falls Formation. Relative to the Bakken data, Smalls Falls samples that have more than $4 \mathrm{wt} \%$ total S are depleted in Mo by at least 20 to $70 \mathrm{ppm}$.

\section{Comparisons to median black shale}

The evaluation of geochemical changes in black shale during diagenesis and low-grade metamorphism requires data for unmetamorphosed samples for use as a baseline composition. However, no such samples were available for this study. As a result, we compare our analyses for the Smalls Falls Formation to a global database of black shale geochemistry (Ketris and Yudovich 2009), and emphasize that the latter is not considered a premetamorphic equivalent of Smalls Falls samples. Note that this global database does not include highly metalliferous black shales (cf. Coveney 2003; Johnson et al. 2017).

Table 2 presents basic statistics for trace elements and REE, together with the global data for median black shale as compiled by Ketris and Yudovich (2009). Data for average shale (Li and Schoonmaker 2003) are shown for comparison. Also listed are median enrichment factors and percent changes calculated in relation to the global median black shale composition. Compared to this black shale median, Th and $\mathrm{Rb}$ in Smalls Falls samples show moderate positive changes of +39.6 and $+41.0 \%$, respectively. Moderate to very large negative changes (-30.0 to $-94.6 \%)$ are evident for $\mathrm{Ge}$, $\mathrm{V}, \mathrm{Cr}, \mathrm{Cu}, \mathrm{Ni}, \mathrm{Cd}, \mathrm{Zn}, \mathrm{Pb}, \mathrm{Au}, \mathrm{Bi}, \mathrm{Tl}, \mathrm{Sb}, \mathrm{As}, \mathrm{Sn}$, and U. Other elements display variable changes in the range of \pm 10 to $\pm 30 \%$. Changes of less than $10 \%$ are not considered significant, given the small database available for this study. Note that the results for some trace elements are not presented due to the limited number of samples $(n=<700)$ reported by Ketris and Yudovich (2009), compared to those for most other trace elements listed in their database $(n>1000$; many $>5000$ ). 


\section{Rare earth element patterns}

Abundances of REE normalized to average Post Archean Australian Shale (PAAS; Taylor and McLennan 1985) range from ca. 0.3 to 2.0 (Fig. 5). Samples from the chlorite and biotite zones display broadly flat patterns with greater total abundances in the former group of samples, and a narrow range of La/Yb ratios (10.4-14.1; Appendix). The middle rare earth elements (MREE) show slight enrichment, relative to PAAS. Three of four garnet-zone samples display significant depletion of light rare earth elements (LREE) with $\mathrm{La} / \mathrm{Yb}$ ratios of 4.7 to 7.7. In the staurolite-andalusite zone, $\mathrm{La} / \mathrm{Yb}$ ratios range from 8.9 to 14.5 ; one sample has enriched heavy
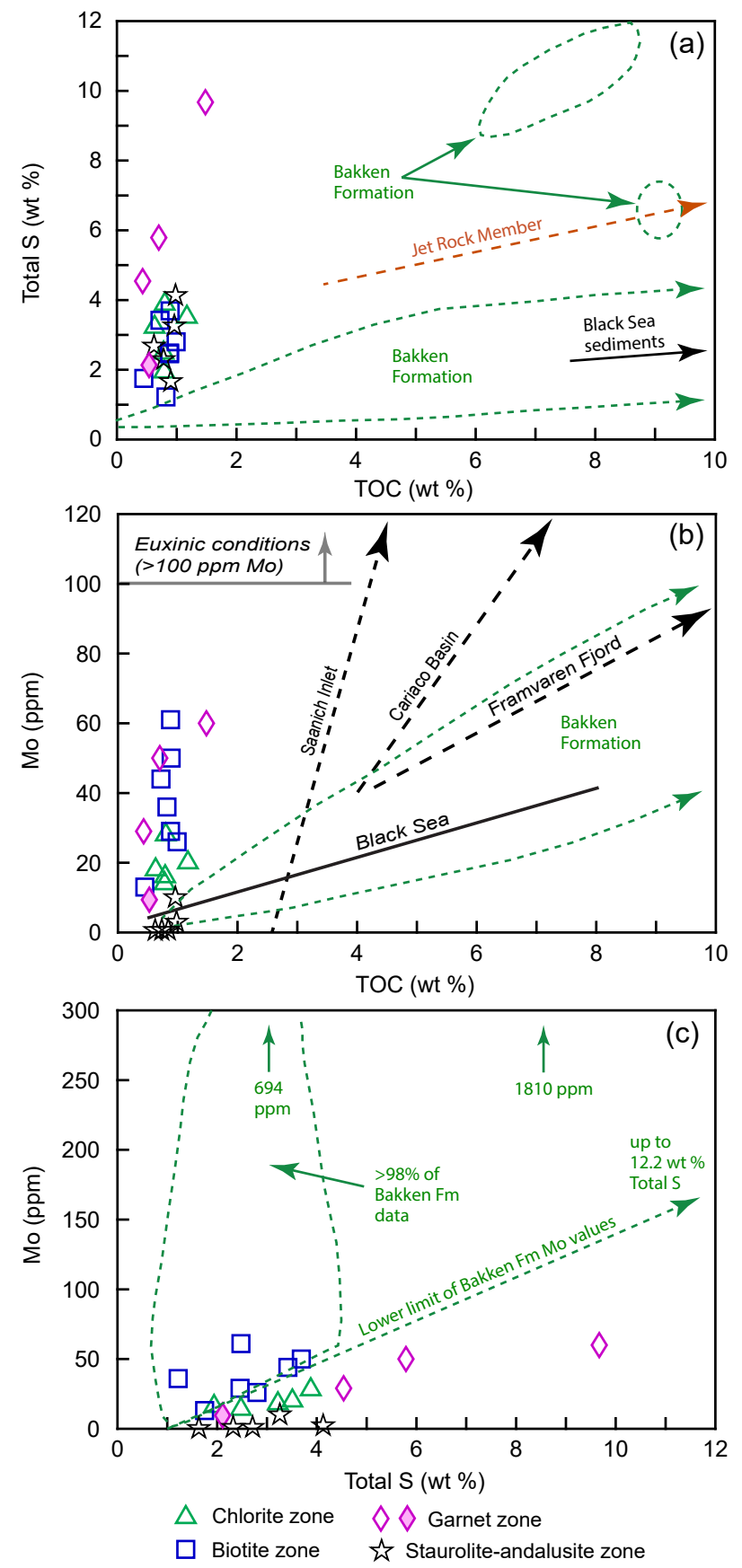

rare earth elements (HREE) compared to samples from the chlorite and biotite zones. No significant Ce anomalies exist, based on calculated $\mathrm{Ce} / \mathrm{Ce}^{\star}$ values (PAAS basis) that range from 0.95 to 1.01. Most samples have $\mathrm{Eu} / \mathrm{Eu}^{*}$ values (PAAS basis) of 0.90 to 1.09 that are neither significantly negative nor positive, but nine samples have small positive anomalies $\left(\mathrm{Eu} / \mathrm{Eu}^{*}=1.10-1.45\right)$; the two highest $\mathrm{Eu} / \mathrm{Eu}^{*}$ values of 1.23 and 1.45 occur in the biotite and garnet zones, respectively. Small positive $\mathrm{Tm}$ anomalies present in all samples are likely analytical artefacts (e.g., Losh and Rague 2018) and are not discussed further.

\section{DISCUSSION}

\section{Provenance}

Strata of the Smalls Falls Formation originated as organicrich clastic sediments that were deposited in a marine basin whose source region lay chiefly to the northwest (present-day coordinates) based on the paleocurrent data of Bradley and Hanson (2002). More insight into provenance of the original sediments comes from immobile trace element ratios, which were likely unaffected by diagenesis and metamorphism thus supporting their use in comparing data for the metamorphic rocks of the Smalls Falls Formation to those of unmetamorphosed sediments. Figure 6 indicates that, with one exception, all samples have $\mathrm{Th} / \mathrm{Sc}$ ratios $>0.5$, which suggests predominantly felsic sources; the trend and range of $\mathrm{Zr} / \mathrm{Sc}$ ratios is consistent with appreciable sediment recycling and zircon concentration (McLennan et al. 1993). This interpretation is supported by the occurrence of predominantly Proterozoic grains in the detrital zircon age spectrum for the Smalls Falls Formation reported by Bradley and O'Sullivan (2016). Use of Sc in such plots may be questioned if this element and related REE were mobile during metamorphism (e.g., Ague 2017); however, strong

Figure 4. Plots of bulk compositions of black phyllite and schist from the Smalls Falls Formation. (a), TOC vs total S. Regression lines for Jurassic Jet Rock Member of the Whitby Mudstone Formation and Holocene Black Sea sediments from Raiswell and Berner (1985) and Lyons and Berner (1992), respectively. (b), TOC vs Mo. Regression lines for anoxic and euxinic sediments of Black Sea, Framvaren Fjord (Norway), Cariaco Basin (offshore Venezuela), and Saanich Inlet (British Columbia) from Algeo and Lyons (2006) and references therein. Minimum Mo content for persistently euxinic (sulphidic) conditions from Scott and Lyons (2012). Note TOC in both plots is total non-carbonate carbon (organic $\mathrm{C}+$ graphitic $\mathrm{C}$ ). (c), total S vs Mo. For samples from garnet zone, open symbols are from location 12; filled symbol is from location 13. Modern suboxic to euxinic marine sediments have total S $<2.5 \mathrm{wt} \%$ and are not shown. Data for Bakken Formation from Scott et al. (2017b, Appendix). 
positive correlations exist between $\mathrm{Al}-\mathrm{Sc}$ and $\mathrm{Ti}-\mathrm{Sc}\left(\mathrm{R}^{2}=\right.$ 0.90 and 0.86 , respectively), which suggest that Sc was relatively immobile assuming that $\mathrm{Al}$ and $\mathrm{Ti}$ were immobile. The variation in $\mathrm{Th} / \mathrm{Sc}$ ratios of samples from location 12 may partly reflect Sc mobility related to channelized fluid flow during metamorphism, as discussed below.

A ternary plot of Th-Sc-Zr/10 (Fig. 7) shows that data for all samples from greenschist-grade outcrops have bulk compositions that fall in the field for continental arcs (Bhatia and Crook 1986). A source from a predominantly felsic arc is thus proposed, an interpretation supported by elevated Sn contents of several analyzed samples, which range up to 29 ppm (Table 2). For comparison (Fig. 8), median Sn in black shale globally is $3.9 \pm 0.3 \mathrm{ppm}$ for all host lithologies and $6.6 \pm 0.4 \mathrm{ppm}$ for terrigenous + volcanic-sedimentary lithologies (Ketris and Yudovich 2009); Sn in average shale is $3 \mathrm{ppm}$ ( $\mathrm{Li}$ and Schoonmaker, 2003). Tin concentrations above ca. $5 \mathrm{ppm}$ in our Smalls Falls samples are unlikely to reflect significant mass loss during metamorphism, because these values are all in biotite-grade samples and because the greatest mass loss in pelitic schists tends to occur at higher grades, in upper greenschist- and amphibolite-facies rocks (e.g., Ague 1994a). The locally high Sn contents reported here, together with elevated $\mathrm{Th} / \mathrm{Sc}$ ratios, suggest an evolved felsic plutonic and/or volcanic source within a former continental arc. In an earlier study, Cullers et al. (1997) reached a similar conclusion for the Smalls Falls Formation based on trace element ratios and REE patterns, albeit for a small data set of only two samples.

Assuming that the early Ludlow graptolite age for the Smalls Falls Formation is valid, a Middle Silurian or older arc is required as a source terrane. Potential candidates include Early Silurian rhyolite in the upper part of the Ascot Complex in southeastern Québec that has a U-Pb zircon date of $441+7 /-12 \mathrm{Ma}$ (David and Marquis 1994). Rhyolites of the Stokes domain, within the Ascot Complex, are derived from an enriched magma with a significant continental crustal component (Tremblay et al. 1989); such evolved felsic magmas typically contain elevated Sn and may have associated tin ores (e.g., Cérný et al. 2005), although no Sn analyses are available for these rhyolites. Additional possible sources are older felsic-dominated arcs as represented by the Early Silurian Attean pluton in northwestern Maine (443 \pm 3 Ma; Gerbi et al. 2006) and by Middle Ordovician rhyolites of the Ascot Complex in southeastern Québec (460 \pm 3 Ma; David and Marquis 1994), but both of these sources are questionable due to the paucity of Paleozoic detrital zircon age peaks older than $437 \mathrm{Ma}$ reported for the Smalls Falls Formation by Bradley and O'Sullivan (2006).

\section{Deposition and diagenesis}

In addition to provenance, the geochemical signature of organic-rich sediments is influenced by depositional parameters including sedimentary sorting, chemical and biological contributions, and the redox state of bottom waters and pore fluids (e.g., Arthur and Sageman 1994; Sageman and
Lyons 2003). Given the moderate to pronounced metamorphic imprint on the Smalls Falls samples used in this study, and the lack of unmetamorphosed equivalents for analysis, it is not possible to evaluate all effects related to sedimentation. However, the mostly very low TOC yet locally high total S contents (Fig. 4a; Appendix) warrant discussion of possible controls including premetamorphic redox state(s).

Numerous geochemical proxies have been employed for evaluating depositional redox states (e.g., Jones and Manning 1994; Rimmer 2004; Tribovillard et al. 2006). However, most trace element proxies used in the past such as Ni/ $\mathrm{Co}, \mathrm{V}+\mathrm{Cr}$, and $\mathrm{V} /(\mathrm{V}+\mathrm{Ni})$ typically yield ambiguous or misleading results (Algeo and Liu 2020; Bennett and Canfield 2020), and hence are not adopted in this study. Among various proxies, one of the more robust for unmetamorphosed black shales is Mo content (Scott and Lyons 2012), which for all 21 samples from the Smalls Falls Formation ranges from less than the detection limit ( $2 \mathrm{ppm}$ ) up to $62 \mathrm{ppm}$. These relatively Mo-poor values suggest that the bottom waters during sedimentation were mainly suboxic to anoxic and lacked persistently euxinic (sulphidic) conditions, based on Mo concentrations of $<100 \mathrm{ppm}$. It is possible that samples having less than $25 \mathrm{ppm}$ Mo record oxic bottom waters (Scott and Lyons 2012), but such values could also reflect dilution by quartz or other clastic components (e.g., Sageman and Lyons 2003). Equally likely, Mo may have been partially lost from the sediments during late diagenesis and/or metamorphism, based on the studies by Wang et al. (2011) and Ardakani et al. (2016) who found widespread mobility of Mo associated with these processes. Also relevant to the paleoredox issue are the small pyrite framboids less than $8 \mu \mathrm{m}$ in diameter (Fig. 3) that occur in one chlorite-zone sample from location 10 (Fig. 1), which are interpreted as primary grains that are preserved through metamorphism. The small size of these framboids suggests that euxinic bottom waters existed during sedimentation there, based on analogy with the size of framboidal pyrite grains in the euxinic water column and sediments of the modern Black Sea (Wilkin et al. 1997) and in unmetamorphosed organic-rich mudrocks that are attributed to euxinic depositional conditions (Wignall and Newton 1998). Uniformly low MnO contents $(<0.01 \mathrm{wt} \%)$ further suggest that the Smalls Falls basin(s) had at least locally anoxic bottom waters (e.g., Quinby-Hunt and Wilde 1994). Smalls Falls samples from the chlorite and biotite zones have log ratios for $\mathrm{U} / \mathrm{Al}$ and $\mathrm{V} / \mathrm{Al}$ of 0.8 to 2.0 and 12 to 23 , respectively, which if largely preserved through greenschist-grade metamorphism, imply deposition under a perennial oxygen minimum zone (see Bennett and Canfield 2020).

Additional insights into depositional conditions come from a plot of TOC vs Mo (Fig. 4b). Except for the Black Sea regression line, those shown for the other modern anoxic to euxinic basins have higher TOC contents and much higher $\mathrm{Mo} / \mathrm{TOC}$ ratios. The Black Sea trend reflects a special case in which the basin is largely restricted from exchange with Mobearing oxic seawater, thus producing Mo-poor euxinic sediments. Different trends shown for the three other examples 
Table 2. Basic statistics for trace elements and rare earth elements in the Smalls Falls

Formation and in marine shale and black shale.

\begin{tabular}{|c|c|c|c|c|c|}
\hline Element & $\begin{array}{l}\text { Median (range) } \\
\text { Smalls Falls Fm. }\end{array}$ & $\begin{array}{l}\text { Avg marine } \\
\text { shale }^{1}\end{array}$ & $\begin{array}{c}\text { Median black } \\
\text { shale }^{2}\end{array}$ & $\begin{array}{l}\text { Median enrich- } \\
\text { ment factor }\end{array}$ & $\begin{array}{l}\text { Percent } \\
\text { change }\end{array}$ \\
\hline Li (ppm) & $40.0(30-100)$ & 66 & $44 \pm 2$ & 0.87 & -13 \\
\hline $\mathrm{Be}$ & $<5$ & 3 & $2.4 \pm 0.2$ & no data & no data \\
\hline $\mathrm{Ga}$ & $19.0(10-30)$ & 19 & $20 \pm 1$ & 0.909 & -9.1 \\
\hline $\mathrm{Ge}$ & $2.0(<2-2)$ & 1.6 & $2.8 \pm 0.2$ & 0.683 & -31.7 \\
\hline $\mathrm{Sc}$ & $14.0(6-21)$ & 13 & $14 \pm 1$ & 0.957 & -4.3 \\
\hline $\mathrm{V}$ & $112.0(61-217)$ & 130 & $200 \pm 10$ & 0.536 & -46.4 \\
\hline $\mathrm{Cr}$ & $70.0(30-100)$ & 90 & $100 \pm 7$ & 0.7 & -30 \\
\hline $\mathrm{Zr}$ & $177.0(97.3-331)$ & 160 & $150 \pm 10$ & 1.129 & 12.9 \\
\hline $\mathrm{Hf}$ & $5.0(3-10)$ & 5 & $3.8 \pm 0.5$ & 1.259 & 25.9 \\
\hline $\mathrm{Nb}$ & $12.0(7-18)$ & 11 & $12 \pm 1$ & 0.957 & -4.3 \\
\hline $\mathrm{Ta}$ & $0.80(<0.5-1.3)$ & 1.3 & $0.83 \pm 0.09$ & not reported ${ }^{4}$ & not reported ${ }^{4}$ \\
\hline $\mathrm{Rb}$ & $137.0(54.3-221)$ & 140 & $93 \pm 9$ & 1.41 & 41 \\
\hline $\mathrm{Sr}$ & $177.0(47.0-330)$ & 170 & $200 \pm 10$ & 0.847 & -15.3 \\
\hline Cs & $7.10(2.1-13.6)$ & 5 & $5.9 \pm 1.0$ & 1.151 & 15.1 \\
\hline $\mathrm{Ba}$ & $436(187-801)$ & 580 & $560 \pm 60$ & 0.745 & -25.5 \\
\hline $\mathrm{Y}$ & $25.5(13.8-45.6)$ & 26 & $29 \pm 1$ & 0.841 & -15.9 \\
\hline $\mathrm{La}$ & $33.0(11.7-48.9)$ & 43 & $31 \pm 2$ & 1.019 & 1.9 \\
\hline $\mathrm{Ce}$ & $71.2(25.7-107)$ & 82 & $61 \pm 6$ & 1.117 & 11.7 \\
\hline $\operatorname{Pr}$ & $8.57(3.20-12.3)$ & 9.8 & $4.1 \pm 0.5$ & not reported ${ }^{4}$ & not reported ${ }^{4}$ \\
\hline $\mathrm{Nd}$ & $31.3(11.9-45.2)$ & 33 & $25 \pm 3$ & 1.198 & 19.8 \\
\hline $\mathrm{Sm}$ & $6.10(2.6-8.8)$ & 6.2 & $4.5 \pm 0.5$ & 1.297 & 29.7 \\
\hline $\mathrm{Eu}$ & $1.32(0.67-2.12)$ & 1.2 & $1.1 \pm 0.06$ & 1.148 & 14.8 \\
\hline $\mathrm{Gd}$ & $5.32(2.72-8.82)$ & 5.1 & $5.5 \pm 0.5$ & 0.926 & -7.4 \\
\hline $\mathrm{Tb}$ & $0.88(0.48-1.27)$ & 0.84 & $0.6 \pm 0.02$ & not reported ${ }^{4}$ & not reported ${ }^{4}$ \\
\hline Dy & $4.91(2.58-7.99)$ & 4.7 & $3.9 \pm 0.4$ & not reported ${ }^{4}$ & not reported ${ }^{4}$ \\
\hline Ho & $0.96(0.47-1.58)$ & 1.1 & $0.57 \pm 0.04$ & not reported ${ }^{4}$ & not reported ${ }^{4}$ \\
\hline Er & $2.91(1.54-5.17)$ & 4.1 & $2.0 \pm 0.1$ & not reported ${ }^{4}$ & not reported ${ }^{4}$ \\
\hline $\mathrm{Tm}$ & $0.49(0.25-0.85)$ & 0.44 & $0.30 \pm 0.03$ & not reported ${ }^{4}$ & not reported ${ }^{4}$ \\
\hline $\mathrm{Yb}$ & $2.80(1.5-5.3)$ & 2.8 & $2.9 \pm 0.2$ & 0.924 & -7.6 \\
\hline $\mathrm{Lu}$ & $0.48(0.23-0.83)$ & 0.42 & $0.40 \pm 0.01$ & 1.148 & 14.8 \\
\hline $\mathrm{Cu}$ & $41.0(24-64)$ & 45 & $100 \pm 8$ & 0.392 & -60.8 \\
\hline $\mathrm{Ni}$ & $58.0(34-82)$ & 50 & $84 \pm 6$ & 0.661 & -33.9 \\
\hline Co & $22.4(12.6-38.6)$ & 19 & $17 \pm 2$ & 1.261 & 26.1 \\
\hline $\mathrm{Cd}$ & $0.30(<0.2-1.3)$ & 0.3 & $5.3 \pm 1.3$ & 0.054 & -94.6 \\
\hline $\mathrm{Zn}$ & $70.0(6-132)$ & 95 & $140 \pm 20$ & 0.478 & -52.2 \\
\hline $\mathrm{Pb}$ & $18.0(11-34)$ & 20 & $29 \pm 2$ & 0.594 & -40.6 \\
\hline Mo & $20.0(<2-61)$ & 2.6 & $18 \pm 3$ & 1.063 & 6.3 \\
\hline $\mathrm{Ag}$ & $<1$ & 0.07 & $1.9 \pm 0.3$ & no data & no data \\
\hline $\mathrm{Au}(\mathrm{ppb})$ & $5.0(<3-38)$ & 2.5 & $8.8 \pm 7.7$ & 0.544 & -45.6 \\
\hline $\mathrm{Pd}(\mathrm{ppb})$ & $3.0(<3-9)$ & 1 & no data & no data & no data \\
\hline $\mathrm{Pt}(\mathrm{ppb})$ & $5.0(2-8)$ & 1 & no data & no data & no data \\
\hline
\end{tabular}


Table 2. Continued.

\begin{tabular}{cccccc}
\hline Element & $\begin{array}{c}\text { Median (range) } \\
\text { Smalls Falls Fm. }\end{array}$ & $\begin{array}{c}\text { Avg marine } \\
\text { shale }\end{array}$ & $\begin{array}{c}\text { Median black } \\
\text { shale }^{2}\end{array}$ & $\begin{array}{c}\text { Median enrich- } \\
\text { ment factor }\end{array}$ & Percent \\
change
\end{tabular}

(Saanich Inlet, Cariaco Basin, Framvaren Fjord) also record varying degrees of basin restriction and seawater ventilation of deep waters (Algeo and Lyons 2006). Although the slope of the trend for the Smalls Falls data is like that for Saanich Inlet, this similarity does not require a link between them in terms of depositional redox conditions.

Organic $\mathrm{C}$ and total $\mathrm{S}$ contents may change greatly during diagenesis. In this context, diagenesis includes both early biogeochemical cycling in sediments and later processes prior to, during, and after lithification. Raiswell and Berner (1987) found that TOC/S ratios in marine sediments progressively decrease with increasing vitrinite reflectance, yielding an average TOC/S ratio of approximately 1.9 and a ca. 30\% loss of organic $\mathrm{C}$ at the beginning of thermal maturity and hydrocarbon generation, to an average TOC/S ratio of approximately 0.6 and total organic $\mathrm{C}$ loss of ca. $70 \%$ at the anthracite grade of organic metamorphism. These ratios reflect not only pyrite formation but also the loss of organic $\mathrm{C}$ by bacterial methane generation and hydrocarbon expulsion (Raiswell and Berner 1986). Ratios of TOC/S for the Smalls Falls Formation, for all metamorphic zones, average $0.41 \pm 0.16$ (Appendix). For comparison, Berner and Raiswell (1983) proposed a much higher organic C/pyrite $S$ ratio of ca. 6.3 for sedimentary rocks of similar Late Silurian age. Based on these comparisons, together with TOC and sulphur data for modern and ancient anoxic to euxinic sediments (Fig. 4a), we estimate that Smalls Falls strata lost approximately 2 to $6 \mathrm{wt} \%$ organic $\mathrm{C}$ during diagenesis.

Diagenetic effects on trace elements in organic-rich mudstones and black shales have received considerable atten- tion. Hannigan and Basu (1998) found depletions in Th and LREE, and enrichment in $\mathrm{U}$ during late diagenesis, based on data for immature $\left(20^{\circ}-50^{\circ} \mathrm{C}\right)$, mature and oil-bearing $\left(50^{\circ}-140^{\circ} \mathrm{C}\right)$, and post-mature $\left(>200^{\circ} \mathrm{C}\right)$ strata of Late Ordovician age from Québec, Ontario, and New York, respectively. Abanda and Hannigan (2006) concluded that V, Cr, $\mathrm{Ba}, \mathrm{Th}, \mathrm{Zr}$, and REE were depleted in thermally mature and post-mature samples, relative to concentrations in immature samples, and that the post-mature samples have higher U, Sr, and Co by comparison. In contrast, Scott et al. (2017a) reported a loss of ca. $30 \%$ organic $\mathrm{C}$ in one sample from the Late Devonian-Early Mississippian Bakken Formation in North Dakota, attributed to thermal effects during late diagenesis at or above the thermal window for oil generation $\left(\sim 60-120^{\circ} \mathrm{C}\right)$, but no significant variation in trace metal/ TOC ratios for other samples having burial conditions ranging from thermal immaturity to the peak oil window. However, significant amounts of $\mathrm{V}$ and $\mathrm{Ni}$, and locally other metals such as $\mathrm{Mo}, \mathrm{Cu}$, and $\mathrm{Zn}$, may be lost at thermal maturity based on their high concentrations in some crude oils (Lewan 1984; Ventura et al. 2015; Yang et al. 2018b). Given the pervasive metamorphic overprint on the Smalls Falls samples, a proper evaluation of possible diagenetic loss of selected metals such as $\mathrm{Cr}, \mathrm{V}$, and $\mathrm{Zn}$ cannot be done. However, loss of Mo is possible given that chlorite-zone sample JS-13-10B contains $28 \mathrm{ppm}$ (Appendix), which is slightly low based on the presence in this sample of small pyrite framboids (Fig. 3) that suggest at least intermittent euxinic conditions and a related Mo concentration of 30 to $70 \mathrm{ppm}$ in coeval sediments (Scott and Lyons 2012). 

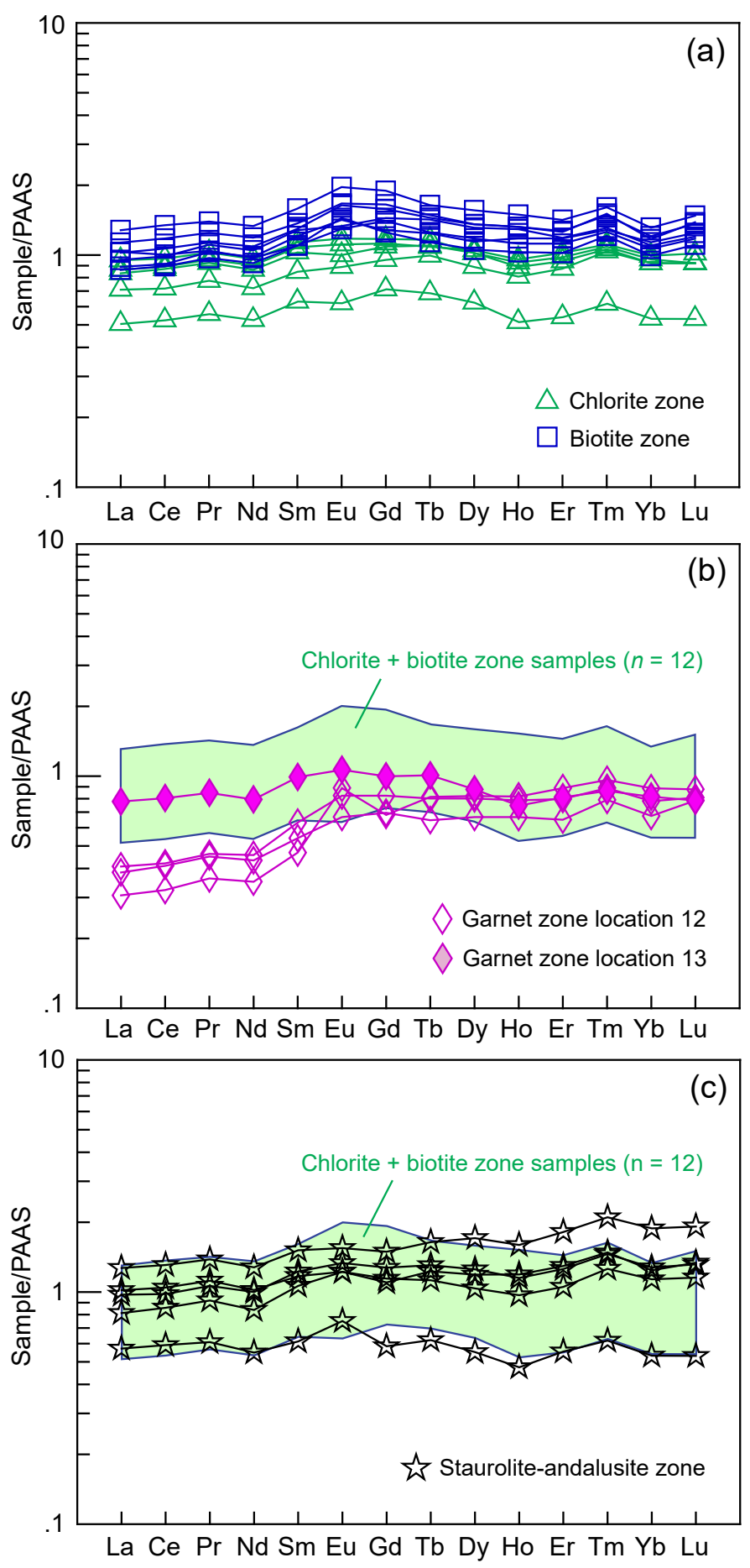

Figure 5. Shale-normalized plots of rare earth element abundances in black phyllite and schist from the Smalls Falls Formation. (a), Samples from chlorite and biotite zones. (b), Samples from garnet zone compared to those from chlorite + biotite zones. (c), Samples from staurolite-andalusite zone compared to those from chlorite + biotite zones. Normalization values are average PostArchean Australian Shale (PAAS) from Taylor and McLennan (1985).
Some unmetamorphosed black shales show evidence for local redistribution of REE. For example, Lev et al. (1999) described altered $\mathrm{La} / \mathrm{Sm}$ ratios and variable $\mathrm{Ce} / \mathrm{Ce}^{*}$ values beyond the range of those reported for unaltered sediments and sedimentary rocks, reflecting one or more periods of dissolution and reprecipitation of REE-bearing minerals (e.g., monazite, apatite) at the sediment-water interface and/ or during early to late diagenesis (see Lev and Filer 2004, and references therein). However, all Smalls Falls samples analyzed in our study have $\mathrm{Ce} / \mathrm{Ce}^{*}$ values of 0.95 to 1.01 (Appendix), which are typical for unaltered sedimentary rocks (e.g., Taylor and McLennan 1985), thus arguing against appreciable Ce redistribution during diagenesis (or metamorphism). Moreover, five samples from the chlorite zone lack positive $\mathrm{Eu}$ anomalies $\left(\mathrm{Eu} / \mathrm{Eu}^{*}=0.90-0.97\right.$; Appendix), suggesting little if any influence on precursor sediments by reduced hydrothermal fluids during diagenesis. Minor enrichment of MREE observed in samples from the chlorite and biotite zones, relative to PAAS (Fig. 5a), may reflect mobility of these elements during low-grade metamorphism and/or earlier diagenesis (e.g., Lev and Filer 2004).

\section{Metamorphism}

\section{Geochemical trends}

Varying degrees of sedimentary sorting and primary detrital vs biological contributions, plus the limited database of our study, preclude a detailed quantitative assessment of metamorphic effects on major-element compositions of the Smalls Falls samples. However, some generalizations can be made. These are typically based on element normalization to either $\mathrm{Al}$ or $\mathrm{Ti}$ and on the assumption that these two elements are conservative components in the sample set, a hypothesis supported by low variance of the $\mathrm{Al} / \mathrm{Ti}$ ratio among all samples analyzed regardless of metamorphic grade (avg $=17.8 \pm 1.51$ ).

Changes in average $\mathrm{Si} / \mathrm{Al}$ ratios show a general decrease with increasing metamorphic grade (Appendix). These changes are, as follows: (1) chlorite zone $=5.73 \pm 1.98(n=$ 5); (2) biotite zone $=3.88 \pm 0.90(n=7)$; (3) garnet zone $=3.91$ (excluding location 12); and (4) staurolite-andalusite zone $=2.97 \pm 0.82(n=5)$. This progressive decrease in $\mathrm{Si} /$ $\mathrm{Al}$ ratios with increasing metamorphism is consistent with the results of more detailed studies in other metamorphic terranes that suggest silica is increasingly lost with increased grade of metamorphism (e.g., Ague 1994a, 2017; Ferry 1994; Masters and Ague 2005). The lowest Si/Al ratios found for samples from the staurolite-andalusite zone are thus attributed here to a major loss of silica that accompanied the P-T-X conditions of this metamorphism. Other major elements in the Smalls Falls database lack significant variations in Al-normalized ratios, except for anomalously high $\mathrm{Fe} / \mathrm{Al}$ of 1.37 and 1.45 in two samples from the garnet zone at location 12 , relative to average ratios of 0.51 to 0.87 for the other three zones (Appendix). All three samples from location 12 have the highest total S contents (4.54-9.67 wt \%), reflected 


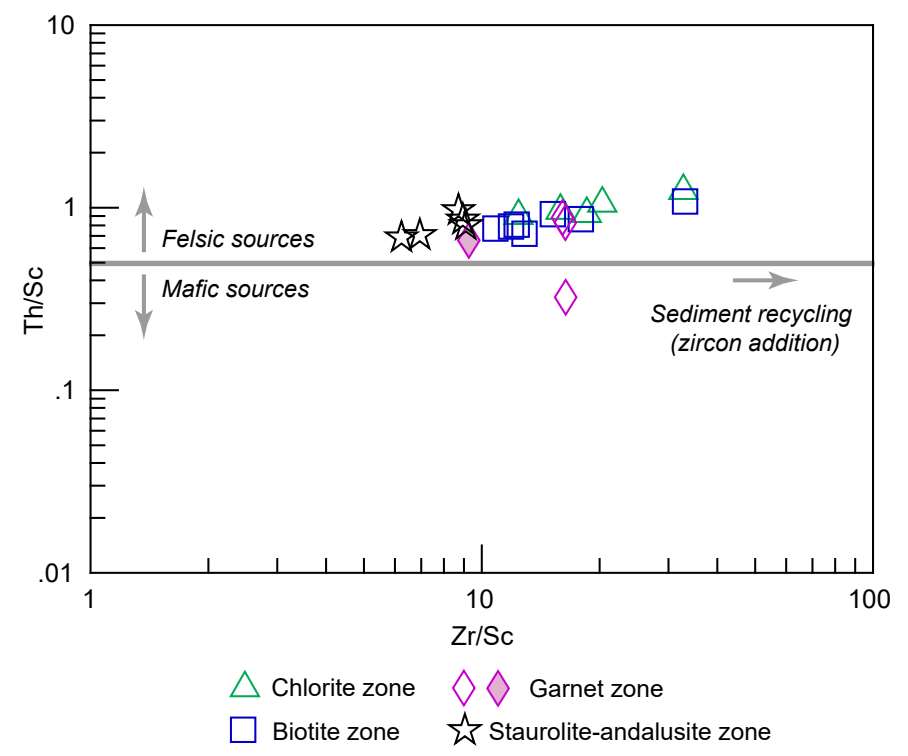

Figure 6. Binary $\mathrm{Zr} / \mathrm{Sc}$ vs $\mathrm{Th} / \mathrm{Sc}$ plot of bulk compositions of black phyllite and schist from the Smalls Falls Formation. For samples from garnet zone, open symbols are from lo-cation 12; filled symbol is from location 13. Discriminant values from McLennan et al. (1993).

in relatively abundant pyrite (Fig. 2c).

Data for the Smalls Falls Formation also suggest an overall loss of TOC with increasing metamorphic grade. Average $\mathrm{TOC} / \mathrm{Al}$ ratios for the chlorite, biotite, garnet, and staurolite-andalusite zones are $0.25 \pm 0.05,0.10 \pm 0.02,0.16 \pm$ 0.08 , and $0.09 \pm 0.02$, respectively. The greatest TOC loss appears to have occurred as a result of $\mathrm{P}-\mathrm{T}$ conditions that existed within the biotite zone, which in western Maine had pressures below $330 \pm 40 \mathrm{MPa}$ and temperatures below 525 $\pm 30^{\circ} \mathrm{C}$ as determined for the staurolite-andalusite zone in this region by Holdaway et al. (1982). Average total S/Al ratios also decrease with increasing metamorphic grade in our Smalls Falls database, from $0.59 \pm 0.24$, to $0.33 \pm 0.11$, to 0.30 (location 13 only), to $0.28 \pm 0.08$, in the chlorite, biotite, garnet, and staurolite-andalusite zones, respectively; these results indicate that the relatively high absolute total S contents among Smalls Falls samples-including up to $3.9 \mathrm{wt} \%$ in the chlorite zone-are unrelated to enrichment due to mass loss during metamorphism, which should produce the opposite trend. Nitrogen (as ammonium ion in micas) also shows a progressive loss in concentration with increasing metamorphic grade in samples from the Smalls Falls Formation (Van Baalen 2006).

Table 3 lists median enrichment factors and percent changes for selected trace elements and REE in the four metamorphic zones sampled in this study. These values were calculated on a Ti-normalized basis relative to the global median black shale of Ketris and Yudovich (2009); $\mathrm{Al}$ was not used because this element is not listed in their database. A statistical evaluation of the observed geochemical variations has been performed by the Tukey-Kramer analysis of variance method (Kramer 1956; Dunnett 1980),

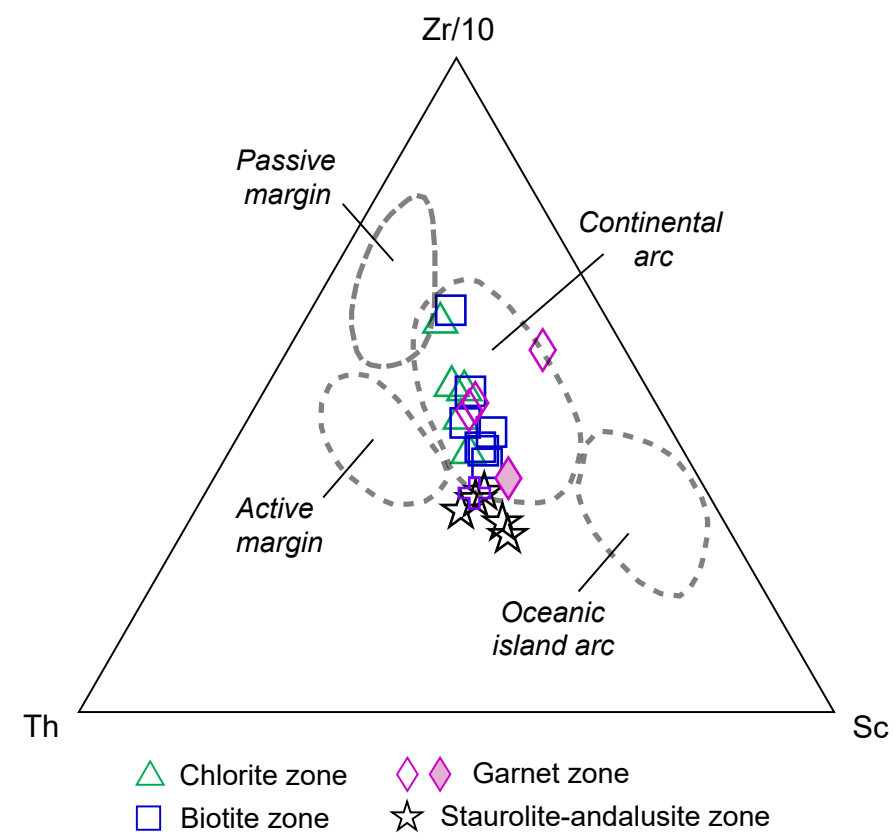

Figure 7. Ternary Zr-Th-Sc plot of bulk compositions of black phyllite and schist from the Smalls Falls Formation. For samples from garnet zone, open symbols are from lo-cation 12; filled symbol is from location 13. Fields from Bhatia and Crook (1986).

using JMP software v. 14.3.0 (SAS Institute Inc. 2018). The Tukey-Kramer test analysis controls for group variance and differences in group sample size by calculating significance difference tests for each group of sample means and medians. Results of this analysis, for selected trace elements in our Smalls Falls database (V, Cr, Y, Cu, Ni, Zn, Pb, Th, U), verify the differences in Ti-normalized values reported here for the four metamorphic zones.

The Ti-normalized values show moderate to large decreases $(-23.1$ to $-49.8 \%)$ for $\mathrm{V}, \mathrm{Cr}, \mathrm{Cu}, \mathrm{Ni}, \mathrm{Zn}, \mathrm{Pb}, \mathrm{Sb}$, and $\mathrm{U}$ in the chlorite zone, attributed here to undefined factors during sedimentation and to selective mobility during diagenesis. Systematic small to extreme decreases (-14.5 to $-99.0 \%$ ) were found for $\mathrm{Ba}, \mathrm{Sb}, \mathrm{Au}$, and $\mathrm{U}$ with increasing metamorphic grade (biotite through staurolite- andalusite), together with less-systematic moderate to large decreases (-35.4 to $-61.1 \%)$ for $\mathrm{V}$ and As. Molybdenum displays progressive increases until the staurolite-andalusite zone in which values greatly decrease $(-94.7 \%)$. Values for $\mathrm{V}, \mathrm{Cr}$, and $\mathrm{U}$ display uniformly moderate to large decreas-es throughout all four metamorphic zones. Enrichment factors and percent changes for $\mathrm{Y}$ and REEs show moderate to large decreases from the biotite to garnet zones (e.g., $-47.3 \%$ for La), probably reflecting the breakdown of apatite and monazite; a similar decrease for Sr (-43.2\%) may record metamorphic decarbonation reactions. Moderate to large increases calculated for $\mathrm{Rb}(+28.1$ to $+61.5 \%)$ and $\mathrm{Th}(+39.1$ to $+47.3 \%)$ from the biotite to staurolite-andalusite zones likely reflect alkali introduction and mass loss, respectively, during metamorphism (e.g., Ague 1994a). 


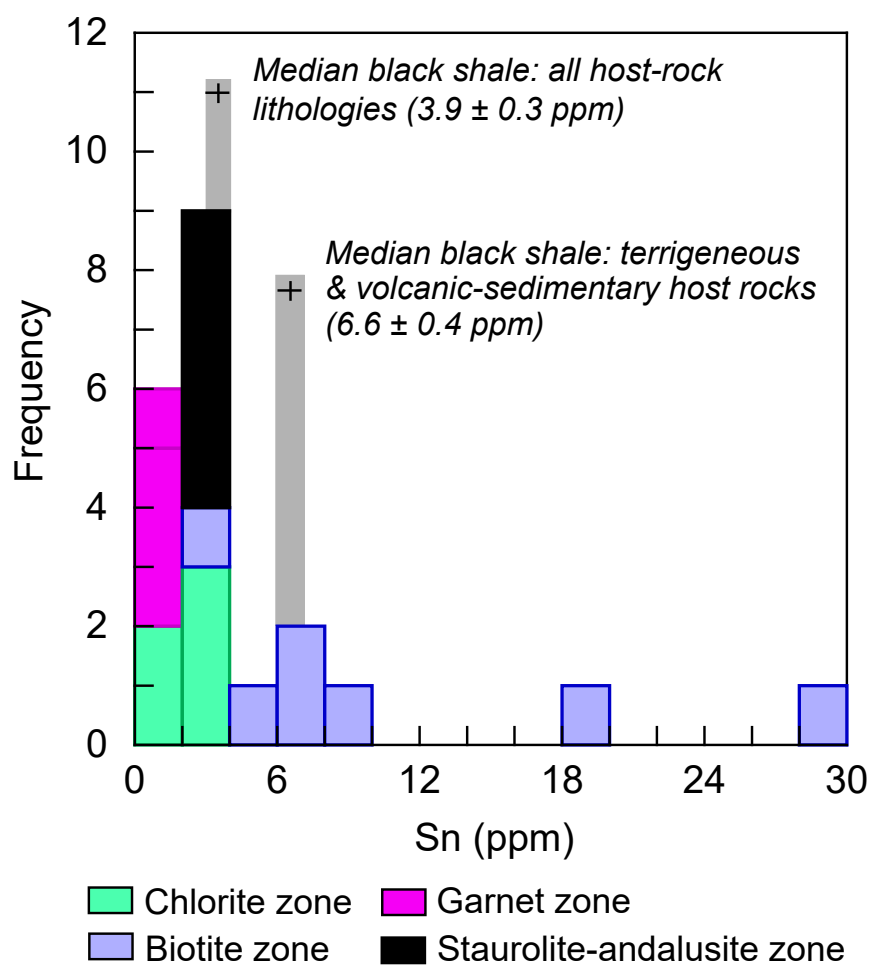

Figure 8. Histogram of tin contents of black phyllite and schist from the Smalls Falls Formation. Shown for comparison are values for global median black shale compositions (Ketris and Yudovich 2009) for two lithologic categories of host rocks: (1) chert + carbonate + terrigenous + volcanic-sedimentary rocks $(n=8040)$, and (2) terrigenous + volcanic-sedimentary rocks $(n=4480)$.

\section{Organic carbon and iron sulphide transformations}

Detailed mineralogical studies have documented the residence of many trace elements in $\mathrm{OM}$ and iron sulphides. For example, Ripley et al. (1990) analyzed the unmetamorphosed Upper Devonian-Lower Mississippian New Albany Shale in Indiana and found that kerogen contains $20 \%$ of the Mo and $50 \%$ of the Ni, whereas iron sulphide contains ca. 56 to $85 \%$ of the Mo, $45 \%$ of the $\mathrm{Ni}$, and essentially all of the $\mathrm{Zn}$, $\mathrm{Cu}$, and $\mathrm{Cd} ; \mathrm{Pb}$ resides in selenide and pyrite. Chappaz et al. (2014) reported that 80 to $100 \%$ of the Mo in euxinic shales resides in the non-sulphide matrix, whereas a maximum of $20 \%$ occurs in pyrite. A more recent study of Mo speciation in Ordovician black shales of southern Québec by Ardakani et al. (2016) documented the presence of $61 \pm 5 \% \mathrm{Mo}(\mathrm{VI})$ in $\mathrm{OM}$ and $39 \pm 5 \% \mathrm{Mo}(\mathrm{IV}) \mathrm{S}_{2}$ as molybdenite. Abanda and Hannigan (2006) reported on leaching experiments of correlative black shales in Québec, Ontario, and New York, and related mass-balance calculations that suggest about $22 \%$ of the trace element and REE contents are contained in the organic fraction. Given the abundances of trace elements and REE in the OM of many unmetamorphosed black shales, the common transformation of largely amorphous OM into variably crystalline graphite during metamorphism may greatly alter the mineralogical residence and whole-rock budget of these elements. The OM to graphite transformation, which depends on several parameters including temperature, pressure, and metamorphic fluid composition (especially $f_{\mathrm{CH} 4}$ ), generally begins in the greenschist facies and is complete, i.e., only fully ordered graphite is present, within the upper amphibolite facies (e.g., Nishimura et al. 2000). However, in some terranes, graphitization is complete by the upper greenschist facies (Wang 1989), whereas in others no correlation exists between metamorphic grade and the degree of graphite crystallinity (Wintsch et al. 1981; Krribek et al. 2008). Nonetheless, the well-documented graphitization of OM during the metamorphism of black shales elsewhere suggests that this process governed, at least in part, the uniformly negative median enrichment factors and percent changes observed for $\mathrm{U}, \mathrm{V}, \mathrm{Cr}$, and $\mathrm{Ni}$ in our samples from the Smalls Falls Formation (Table 3).

Metals in black shales that are contained mainly in iron sulphide minerals can also be lost during the metamorphic recrystallization of pyrite and the transformation of pyrite to pyrrhotite. Recrystallization of pyrite commonly releas-es numerous trace elements, based on in situ laser ablationinductively coupled plasma-mass spectrometry (LA-ICPMS) analysis of different pyrite generations in black shale (Large et al. 2007, 2011; Gregory et al. 2016). In pelitic schists, the pyrite to pyrrhotite transformation commonly begins in the middle to upper greenschist facies with the breakdown of chlorite (as a major source of fluid) and is complete by the upper greenschist to upper amphibolite facies, depending on various physicochemical parameters (e.g., Ferry 1981; Tomkins 2010). In our samples of metamorphosed black shale from the Smalls Falls Formation, pyrrhotite is absent from the chlorite zone, rare in the biotite zone, uncom-mon in the garnet zone, and predominant in the staurolite- andalusite zone (Fig. 2). The chalcophile elements $\mathrm{Cu}, \mathrm{Zn}, \mathrm{Sb}$, and $\mathrm{As}$, as well as $\mathrm{Mo}, \mathrm{Ni}$, and Co (siderophile), all show uniformly large decreases in median enrichment factors and percent changes in the staurolite-andalusite zone, relative to the garnet zone; $\mathrm{Au}$ and $\mathrm{Sb}$ values progressively decrease above the chlorite zone (Table 3). Considered overall, these decreases suggest preferential loss of chalcophile and some siderophile elements to the fluid phase, related to the meta-morphic recrystallization of pyrite, and to the metamorphic transformation of pyrite to pyrrhotite, with limited ability of the latter mineral to incorporate appreciable amounts of these trace elements. This interpretation is consistent with findings by other workers, based on in situ geochemical data obtained via LA-ICP-MS. For example, Large et al. (2011) described major depletion of $\mathrm{Pb}, \mathrm{Cu}, \mathrm{Zn}, \mathrm{Sb}, \mathrm{Ag}$, $\mathrm{Mo}, \mathrm{Bi}, \mathrm{Te}$, and $\mathrm{Tl}$ in carbonaceous shales during the lowgrade metamorphic recrystallization of pyrite, and substantial loss of $\mathrm{Au}, \mathrm{As}, \mathrm{S}, \mathrm{Sb}, \mathrm{Te}, \mathrm{Cu}, \mathrm{Zn}, \mathrm{Mo}, \mathrm{Bi}, \mathrm{Tl}$, and $\mathrm{Pb}$ in similar rocks at higher grades during the pyrite to pyrrhotite transition. Pitcairn et al. (2010a, 2015) reported pervasive loss of $\mathrm{As}, \mathrm{Au}, \mathrm{Hg}$, and $\mathrm{Sb}$ in amphibolite-facies rocks of the Otago and Alpine schists (New Zealand) and the Dalradian Supergroup (Scotland) that contain only pyrrhotite, relative 
Table 3. Median trace element and REE element enrichment factors and percent changes in Small Falls Formation at different metamorphic grades ${ }^{1}$.

\begin{tabular}{|c|c|c|c|c|c|c|c|c|}
\hline \multirow[b]{2}{*}{ Element } & \multicolumn{2}{|c|}{ Chlorite $(n=5)$} & \multicolumn{2}{|c|}{ Biotite $(n=7)$} & \multicolumn{2}{|c|}{ Garnet $(n=4)$} & \multicolumn{2}{|c|}{$\begin{array}{c}\text { Staurolite- } \\
\text { Andalusite }(n=5)\end{array}$} \\
\hline & $\begin{array}{c}\text { Median } \\
\mathrm{EF}^{3}\end{array}$ & $\begin{array}{l}\text { Percent } \\
\text { Change }\end{array}$ & $\begin{array}{c}\text { Median } \\
\mathrm{EF}^{3}\end{array}$ & $\begin{array}{l}\text { Percent } \\
\text { Change }\end{array}$ & $\begin{array}{c}\text { Median } \\
\mathrm{EF}^{3}\end{array}$ & $\begin{array}{l}\text { Percent } \\
\text { Change }\end{array}$ & $\begin{array}{c}\text { Median } \\
\mathrm{EF}^{3}\end{array}$ & $\begin{array}{l}\text { Percent } \\
\text { Change }\end{array}$ \\
\hline $\mathrm{V}$ & 0.5023 & -49.8 & 0.6003 & -40.0 & 0.5054 & -49.5 & 0.4593 & -54.1 \\
\hline $\mathrm{Cr}$ & 0.5707 & -42.9 & 0.6073 & -39.3 & 0.7490 & -25.1 & 0.6164 & -38.4 \\
\hline $\mathrm{Rb}$ & 1.2765 & 27.7 & 1.2810 & 28.1 & 1.6146 & 61.5 & 1.5507 & 55.1 \\
\hline $\mathrm{Sr}$ & 1.0302 & 3.0 & 1.0961 & 9.6 & 0.5677 & -43.2 & 0.5177 & -48.2 \\
\hline $\mathrm{Ba}$ & 0.8887 & -11.1 & 0.8551 & -14.5 & 0.6961 & -30.4 & 0.6169 & -38.3 \\
\hline $\mathrm{Y}$ & 0.9231 & -7.7 & 0.9227 & -7.7 & 0.7610 & -23.9 & 0.7624 & -23.8 \\
\hline $\mathrm{La}$ & 1.1574 & 15.7 & 1.1072 & 10.7 & 0.5273 & -47.3 & 0.8417 & -15.8 \\
\hline $\mathrm{Eu}$ & 1.1382 & 13.8 & 1.2996 & 30.0 & 0.8862 & -11.4 & 0.8395 & -16.0 \\
\hline $\mathrm{Yb}$ & 0.9722 & -2.8 & 0.9573 & -4.3 & 0.8414 & -15.9 & 0.8444 & -15.6 \\
\hline $\mathrm{Cu}$ & 0.6135 & -38.6 & 0.3482 & -65.2 & 0.5809 & -41.9 & 0.2679 & -73.2 \\
\hline $\mathrm{Ni}$ & 0.7474 & -25.3 & 0.6584 & -34.2 & 0.9394 & -6.1 & 0.4240 & -57.6 \\
\hline Co & 1.2990 & 29.9 & 0.8899 & -11.0 & 2.0625 & 106.0 & 0.9629 & -3.7 \\
\hline $\mathrm{Zn}$ & 0.6507 & -34.9 & 0.3233 & -67.7 & 0.6547 & -34.5 & 0.3258 & -67.4 \\
\hline $\mathrm{Pb}$ & 0.7692 & -23.1 & 0.5048 & -49.5 & 0.5421 & -45.8 & 0.6273 & -37.3 \\
\hline Mo & 1.2683 & 26.8 & 1.8328 & 83.3 & 2.5021 & 150.0 & 0.0532 & -94.7 \\
\hline $\mathrm{Au}$ & 1.1091 & 10.9 & 0.6248 & -37.5 & 0.1930 & -80.7 & 0.1193 & -88.1 \\
\hline $\mathrm{Sb}$ & 0.7293 & -27.1 & 0.4067 & -59.3 & 0.0857 & -91.4 & 0.0097 & -99.0 \\
\hline As & 2.7541 & 175.0 & 0.5091 & -49.1 & 0.6455 & -35.4 & 0.3887 & -61.1 \\
\hline Sn & 0.2987 & -70.1 & 0.9858 & -1.4 & 0.0858 & -91.4 & 0.2900 & -71.0 \\
\hline Th & 1.4894 & 48.9 & 1.4728 & 47.3 & 1.4366 & 43.7 & 1.3914 & 39.1 \\
\hline $\mathrm{U}$ & 0.5255 & -47.4 & 0.7610 & -23.9 & 0.4829 & -51.7 & 0.2125 & -78.7 \\
\hline
\end{tabular}

${ }^{1}$ Data are normalized to values for median black shale (terrigenous + volcanic-sedimentary category) of Ketris and Yudovitch (2009).

${ }^{2}$ TOC values are total non-carbonate carbon that includes both organic C (analyzed) and graphitic C (calculated).

${ }^{3}$ Enrichment factors are calculated by normalization to Ti contents (ppm) in both Smalls Falls Formation and median black shale (Ketris and Yudovitch 2009).

Note: For calculation purposes analyses below detection limits are assigned one half that value (Sanford et al . 1993).

to pyrite-bearing greenschist-facies equivalents in both areas. Following these studies, we suggest that metamorphic devolatilization of Smalls Falls strata transferred numerous trace elements to the fluid phase that were partly to largely removed from the local environment.

The presence of positive $\mathrm{Eu}$ anomalies in some of the Smalls Falls samples is consistent with local influence by reduced metamorphic fluids (e.g., Bau 1991). Importantly, all chlorite-zone samples lack positive anomalies defined as Eu/ $\mathrm{Eu}^{*} \geq 1.10$ (Appendix), thus ruling out redox influence on $\mathrm{Eu}^{2+} / \mathrm{Eu}^{3+}$ equilibria by anoxia or euxinia in synsedimentary to early diagenetic pore fluids (see Slack et al. 2015). Positive Eu anomalies are rare in metasedimentary rocks that are spatially unrelated to hydrothermal ore deposits, thus suggesting a link to the mineralogy and composition of the Smalls Falls strata. Occurrence of abundant iron sulphide within rocks of this formation, together with minor OM and/or graphite, implies that metamorphic fluids in equilibrium with these rocks were reducing and had temperatures greater than $250^{\circ} \mathrm{C}$, and locally produced $\mathrm{Eu}^{2+}$-dominant speciation and resulting positive $\mathrm{Eu}$ anomalies.

\section{Channelized fluid flow}

In addition to mineralogical and geochemical effects from organic carbon and iron sulphide transformations in the Smalls Falls Formation, evidence for channelized fluid flow exists in one outcrop. Samples from location 12, north of the town of Bingham (Fig. 1; Table 1), are atypical in having anomalously high $\mathrm{Fe} / \mathrm{Al}$ and low $\mathrm{La} / \mathrm{Yb}$ ratios, compared to the one sample from location 13 in the same garnet zone and to those analyzed from the other metamorphic zones (Fig. 9). The three samples from location 12 are also compositionally distinct in having the highest total $\mathrm{S}$ contents 


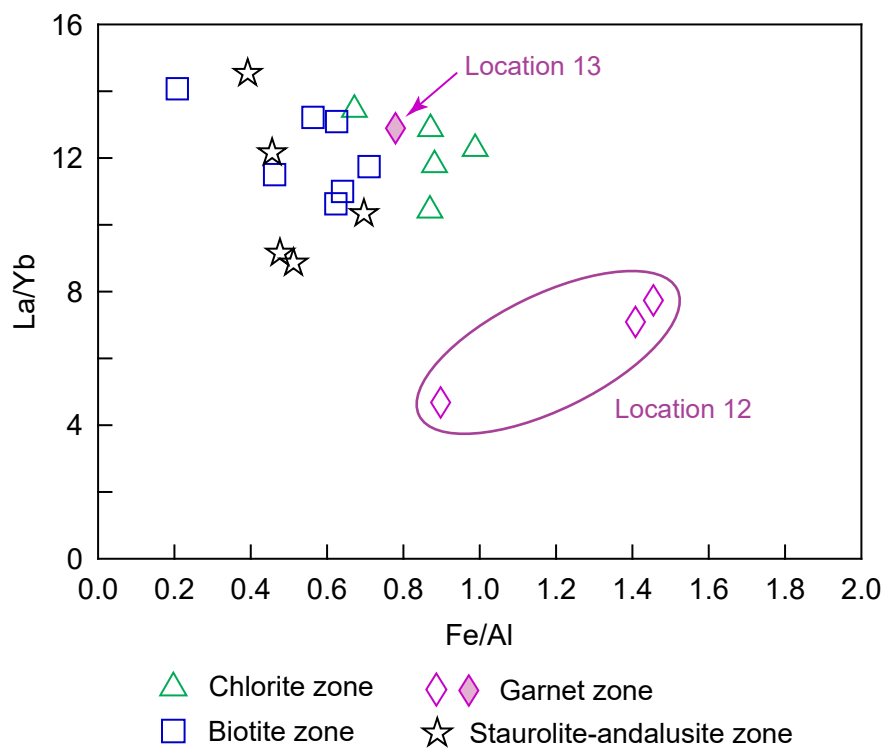

Figure 9. Binary $\mathrm{Fe} / \mathrm{Al}$ vs $\mathrm{La} / \mathrm{Yb}$ plot of bulk compositions of black phyllite and schist from the Smalls Falls Formation.

(4.54-9.67 wt \%; Fig. 4) and highest As (280 ppm) and Co $(38.6 \mathrm{ppm})$, as well as small positive $\mathrm{Eu}$ anomalies $\left(\mathrm{Eu} / \mathrm{Eu}^{*}\right.$ $=1.10-1.45)$. These data suggest that enrichment in pyrite, as a host for the As and Co, and deposition of this pyrite, was from reduced fluids. Predominance of foliated pyrite in these samples (Fig. 2c) indicates that these fluids were introduced before penetrative deformation ended. The distinctly low $\mathrm{La} / \mathrm{Yb}$ ratios imply preferential loss of LREE from the pyritic schist at this site. The sample with the highest $\mathrm{Eu} / \mathrm{Eu}^{*}$ value of 1.45, from location 12, also has the highest $\mathrm{Na}_{2} \mathrm{O}$ content (1.82 wt \%; Appendix), suggesting a metamorphic influx of $\mathrm{Na}$ and related growth of sodic plagioclase that sequestered $\mathrm{Eu}^{2+}$ and a resulting positive Eu anomaly (see Ague 2017). However, compared to the other metamorphic zones, these three samples lack elevated Si/Al ratios (Appendix), consistent with an absence of introduced silica (as quartz) although limited sampling and surface weathering of this outcrop make it difficult to rule out unrecognized metamorphic quartz veins at or near the sample sites.

The geochemical data reported here for location 12 are interpreted to reflect channelized fluid flow during metamorphism. This process has been studied by many workers, because of its importance in driving metamorphic reactions and mass changes in the crust (e.g., Ferry 1994; Ague 1994b, 2017; Skelton et al. 1995; Pitcairn et al. 2010b). Our reconnaissance data for location 12 are consistent with the results of these other, more detailed, studies including for REE (cf. Ague 2017). A thorough evaluation of channelized fluid flow in this outcrop, including possible lithologic and/ or structural controls, awaits further sampling and analysis.

\section{Regional considerations}

On the northwestern margin of the CMB, the Smalls Falls Formation has conformable contacts with both the underly- ing Perry Mountain Formation and overlying Madrid Formation. Point counts of metasedimentary rocks from these formations by Moench (2006) indicate high sediment maturity within the Perry Mountain Formation and the Smalls Falls followed by a marked decrease in maturity in the overlying Madrid Formation. These data suggest that the onset of anoxia reflects changes in the water column rather than in local geologic variables (e.g., provenance). In contrast, the Smalls Falls-Madrid transition constitutes the more significant local geologic change, which has been interpreted to record the switch from a northwestern source to a southeastern one (Bradley et al. 2000).

Regional considerations point to the emergence of a landmass southeast of Central Maine during the Silurian (e.g., Bradley et al. 2000). Specifically, a thick section of sandstones-the Mayflower Hill Formation (of the Vassalboro Group; Marvinney et al. 2010; Ludman et al. 2020) - conformably overlies the dominantly pelitic Wenlock Waterville Formation. Together, these formations define a coarseningupwards sequence prior to termination of sedimentation in the Late Silurian. Plutons of Ludlovian age farther southeast mark closure of the Fredericton Trough on the Dog Bay Line, the presumed mechanism for Silurian uplift and emergence (Reusch and van Staal 2012).

Reusch and van Staal (2012) offered specific mechanisms for how emergence of the southeastern source-the Brunswick subduction complex-might trigger anoxia on the northwest margin of the CMB. These mechanisms include a bathymetric high that cut off exchange with the open ocean, a fresh-water lid that impeded lateral and vertical circulation, and nutrient loading that enhanced productivity and eutrophication. Basin contraction brought the southeastern landmass closer to the site of Smalls Falls sedimentation, until black shale deposition was replaced by a mix of southeasterly derived siliciclastic and carbonate turbidites within the Madrid Formation (Moench 2006). Widespread algal blooms, analogous to those described for other Paleozoic black shales (e.g., Grimm et al. 1997; Macquaker et al. 2010), may have provided the OM responsible for the reducing conditions in bottom waters and pore fluids inferred here for the Smalls Falls sediments.

\section{Potential modern analogs}

Given the geochemical constraints pointing to a variably anoxic depositional environment for the Smalls Falls Formation, several potential modern analogues can be considered. First, upwelling zones such as those offshore Peru and Namibia are rejected as candidates, because the reduced sediments there are locally highly phosphatic and include phosphorites with $\mathrm{P}_{2} \mathrm{O}_{5}$ contents that exceed 18 wt \% (e.g., Föllmi 1996), which contrast with the less than $0.2 \mathrm{wt} \%$ $\mathrm{P}_{2} \mathrm{O}_{5}$ present in Smalls Falls strata (Appendix). Second, very local restricted basins, such as Framvaren Fjord in Norway that has extremely high dissolved sulphide $\left(\mathrm{H}_{2} \mathrm{~S}\right)$ in the water column (e.g., Skei 1983), are far too small to serve as valid analogs. 
Other modern suboxic to euxinic basins to evaluate including the Cariaco Basin, Orca Basin, Southern California Borderland, and Black Sea (cf. Algeo and Tribovillard 2009). However, available geochemical data for the first three of these basins indicate that their contained sediments have uniformly low concentrations of total $S$ or sulphide $S(<2.5$ wt \%; Leslie et al. 1990; Hurtgen et al. 1999; Lyons et al. 2003; Figueroa et al. 2018). These low values contrast with our data for Smalls Falls strata (excluding pyrite-rich samples from location 12) that show $\sim 2$ to $4 \mathrm{wt} \%$ total S including up to $3.9 \mathrm{wt} \%$ total $\mathrm{S}$ in chlorite-grade samples that is unrelated to mass loss during metamorphism. However, the Black Sea differs in having older Holocene sediments (sapropels) with up to $8.3 \mathrm{wt} \%$ total S (Hirst 1974), although younger $(<3200 \mathrm{yr})$ Holocene sediments there contain less than 2.5 wt \% sulphide S (Lyons and Berner 1992). The Black Sea has a history of extension-related subsidence and a current foreland tectonic setting, like the ancestral CMB, and has been cut off from oxygenated Mediterranean waters throughout its $\sim 1200-\mathrm{km}$ width (Lyons and Berner 1992). This tectonic setting and local presence of sulphide-rich sediments in the Black Sea suggests that it may serve as a potential analog of the basin(s) in which strata of the Smalls Falls Formation accumulated. If this comparison is valid, it could also explain the anomalously low Mo contents of the Smalls Falls samples, relative to those of the Black Sea (Fig. $4 \mathrm{~b}$ ), by limited ventilation of Mo-bearing oxygenated seawater into the $\mathrm{CMB}$ during the Ludlovian.

\section{Suggestions for future work}

This reconnaissance study involved the analysis of only 21 samples from one stratigraphic unit (and correlatives) ca. $300 \mathrm{~km}$ in strike length (Fig. 1). As a result, only broad interpretations can be made, given the likelihood of unrecognized differences in trace element and REE concentrations at single locations and even within thin $(<5 \mathrm{~cm})$ beds, as a function of sedimentary sorting, rapid variations in redox state of bottom waters, and superimposed effects of diagenesis and metamorphism. Future work on the Smalls Falls Formation should obtain analyses of many more samples in a systematic approach that tests these parameters, including our hypothesis for synmetamorphic channelized fluid flow proposed at location 12 in western Maine. Worthwhile also would be in situ analysis, via LA-ICP-MS, of trace elements in pyrite and pyrrhotite (and other sulphides) using samples from different metamorphic grades, as a means to better evaluate the loss of metals during the transformation of pyrite to pyrrhotite.

\section{ACKNOWLEDGMENTS}

We dedicate this paper to the late Robert H. Moench, who led the way for decades in efforts to unravel the geological setting and evolution of the Smalls Falls Formation and enclosing strata in western Maine. We also acknowledge the late Charles V. Guidotti for pioneering mineralogical and petrological studies of the Smalls Falls Formation, and who, like Bob Moench, guided us on numerous field trips in the region. Gary M. Boone, Alan Ludman, and Darrell J. Henry are thanked for discussions. Brett J. Valentine of the USGS assisted in SEM-BSE imaging.

The manuscript benefited from detailed USGS reviews by Rob Robinson and Clint Scott, who provided numerous suggestions on statistics and paleoredox, respectively. Paul Tomascak and Dan Gregory are thanked for constructive journal reviews; we especially appreciate the many critical comments of Tomascak that helped shape and focus the final paper.

Any use in this paper of trade, firm, or product names is for descriptive purposes only and does not imply endorsement by the U.S. Government.

\section{REFERENCES}

Abanda, P.A. and Hannigan, R.E. 2006. Effect of diagenesis on trace element partitioning in shales. Chemical Geology, 230, pp. 42-59. https://doi.org/10.1016/j.chemgeo.2005.11.011

Ague, J.J. 1991. Evidence for major mass transfer and volume strain during regional metamorphism of pelites. Geology, 19, pp. 855-858. https://doi.org/10.1130/0091-761 3(1991)019<0855:EFMMTA >2.3.CO;2

Ague, J.J. 1994a. Mass transfer during Barrovian metamorphism of pelites, south-central Connecticut. I: evidence for changes in composition and volume. American Journal of Science, 294, pp. 989-1057. https://doi.org/10.2475/ ajs.294.8.989

Ague, J.J. 1994b. Mass transfer during Barrovian metamorphism of pelites, south-central Connecticut. II: channelized fluid flow and the growth of staurolite and kyanite. American Journal of Science, 294, pp. 1061-1134. https:// doi.org/10.2475/ajs.294.9.1061

Ague, J.J. 2017. Element mobility during regional metamorphism in crustal and subduction zone environments with a focus on the rare earth elements (REE). American Mineralogist, 102, pp. 1796-1821. https://doi.org/10.2138/ am-2017-6130

Algeo, T.J. and Liu, J. 2020. A re-assessment of elemental proxies for paleoredox analysis. Chemical Geology, 540, https://doi.org/10.1016/j.chemgeo.2020.119549

Algeo, T.J. and Lyons, T.W. 2006. Mo-total organic carbon covariation in modern anoxic marine environments: implications for analysis of paleoredox and paleohydrographic conditions: Paleoceanography, 21, PA1016, https://doi.org/10.1029/2004PA001112

Algeo, T.J. and Tribovillard, N. 2009. Environmental analysis of paleoceanographic systems based on molybdenum-uranium covariation. Chemical Geology, 268, pp. 211-225. https://doi.org/10.1016/j.chemgeo.2009.09.001

Ardakani, O.H., Chappaz, A., Sanei, H., and Mayer, B. 2016. Effect of thermal maturity on remobilization of 
molybdenum in black shales. Earth and Planetary Science Letters, 449, pp. 311-320. https://doi.org/10.1016/j. epsl.2016.06.004

Arthur, M.A. and Sageman, B.B. 1994. Marine black shales: depositional mechanisms and environments of ancient deposits. Annual Review of Earth and Planetary Sciences, 22, pp. 499-551. https://doi.org/10.1146/annurev. ea.22.050194.002435

Bau, M. 1991. Rare-earth element mobility during hydrothermal and metamorphic fluid-rock interaction and the significance of the oxidation state of europium. Chemical Geology, 93, pp. 219-230. https://doi.org/10.1016/00092541(91)90115-8

Bennett, W.W. and Canfield, D.E. 2020. Redox-sensitive trace metals as paleoredox proxies: a review and analysis of data from modern sediments. Earth-Science Reviews 204. https://doi.org/10.1016/j.earscirev.2020.103175

Berner, R.A. and Raiswell, R. 1983. Burial of organic carbon and pyrite sulfur in sediments over Phanerozoic time: a new theory. Geochimica et Cosmochimica Acta, 47, pp. 855-862. https://doi.org/10.1016/0016-7037(83)90151-5

Bhatia, M.R. and Crook, K.A.W. 1986. Trace element characteristics of graywackes and tectonic setting discrimination of sedimentary basins. Contributions to Mineralogy and Petrology, 92, pp. 181-193. https://doi.org/10.1007/ BF00375292

Boone, G.M. 1973. Metamorphic stratigraphy, petrology, and structural geology of the Little Bigelow Mountain map area, western Maine. Maine Geological Survey Bulletin 24, $136 \mathrm{p}$.

Boone, G., Boudette, E., and Moench, R.H. 1970. Bedrock geology of the Rangeley Lakes-Dead River region, western Maine. In Guidebook for field trips in the Rangeley Lakes-Dead River basin region, western Maine. Edited by G.M. Boone. New England Intercollegiate Geological Conference, $62^{\text {nd }}$ Annual Meeting, Augusta, Maine, Kennebec Journal Press, pp. 1-24.

Bradley, D.C. and Hanson, L.S. 2002. Paleocurrent analysis of a deformed Devonian foreland basin in the northern Appalachians, Maine, USA. Sedimentary Geology, 148, pp. 425-447. https://doi.org/10.1016/S0037-0738(01)001610

Bradley, D.C. and O'Sullivan, P. 2016. Detrital zircon geochronology of pre- and syncollisional strata, Acadian orogen, Maine Appalachians. Basin Research, 29, pp. 557-570. https://doi.org/10.1111/bre.12188

Bradley, D.C., Tucker, R.D., Lux, D.R., Harris, A.G., and McGregor, D.C. 2000. Migration of the Acadian orogen and foreland basin across the northern Appalachians of Maine and adjacent areas: U.S. Geological Survey Professional Paper 1624, 49 p. https://doi.org/10.3133/pp1624

Cérný, P., Blevin, P.L., Cuney, M., and London, D. 2005. Granite-related ore deposits. In Economic Geology One Hundredth Anniversary Volume, 1905-2005. Edited by J.W. Hedenquist, J.F.H. Thompson, R.J. Goldfarb, and J.P. Richards. Littleton, Colorado, Society of Economic Geologists, Inc., pp. 337-370. https://doi.org/10.5382/
AV100.12

Chappaz, A., Lyons, T.W, Gregory, D.D, Reinhard, C.T, Gill, B.C, Li, C., and Large, R.R. 2014. Does pyrite act as an important host for molybdenum in modern and ancient euxinic sediments? Geochimica et Cosmochimica Acta, 126, pp. 112-122. https://doi.org/10.1016/j.gca.2013.10.028

Coveney, R.M. Jr. 2003. Metalliferous Paleozoic black shales and associated strata. In Inorganic geochemistry of sediments and sedimentary rocks: evolutionary considerations to mineral deposit-forming environments. Edited by D.R. Lentz. Geological Association of Canada, GeoText 4, pp. 135-144.

Cullers, R.L., Bock, B., and Guidotti, C. 1997. Elemental distributions and neodymium isotopic compositions of Silurian metasediments, western Maine, USA: redistribution of the rare earth elements. Geochimica et Cosmochimica Acta, 61, pp. 1847-1861. https://doi.org/10.1016/S00167037(97)00048-3

David, J. and Marquis, R. 1994. Géochronologie U-Pb dans les Appalaches du Québec: application aux roches de la zone de Dunnage. La Revue Géologique, 1, pp. 16-20.

Dunnett, C.W. 1980. Pairwise multiple comparisons in the unequal variance case. Journal of the American Statistical Association, 75, pp. 796-800. https://doi.org/10.1080/016 21459.1980.10477552

Ferry, J.M. 1981. Petrology of graphitic sulfide rich schist from south-central Maine: an example of desulfidation during prograde regional metamorphism. American Mineralogist, 66, pp. 908-931.

Ferry, J.M. 1994. Overview of the petrologic record of fluid flow during regional metamorphism in northern New England. American Journal of Science, 294, pp. 905-988. https://doi.org/10.2475/ajs.294.8.905

Figueroa, M.C., Gregory, D.D., Choumiline, K., LeMieux, S., Treude, T., Berelson, W., Bates, S., and Lyons, T.W. 2018. Unexpected biogeochemical controls from the Santa Monica Basin revealed in carbon, sulfur, and trace metal cycling. Goldschmidt 2018 Conference, August 12-17, Boston, Massachusetts, Abstracts Volume.

Föllmi, K.B. 1996. The phosphorous cycle, phosphogenesis and marine phosphate-rich deposits. Earth-Science Reviews, 40, pp. 55-124. https://doi.org/10.1016/0012$\underline{\text { 8252(95)00049-6 }}$

Gerbi, C.C., Johnson, S.E., Aleinikoff, J.N., Bédard, J.H., Dunning, G.R., and Fanning, C.M. 2006. Early Paleozoic development of the Maine-Quebec Boundary Mountains region. Canadian Journal of Earth Sciences, 43, pp. 367389. https://doi.org/10.1139/e05-113

Granitto, M., Giles, S.A., and Kelley, K.D. 2017. Global geochemical database for critical metals in black shales. U.S. Geological Survey Data Release, https://doi.org/10.5066/ F71G0K7X

Gregory, D.D., Large, R.R., Bath, A.B., Steadman, J.A., Wu, S., Danyushevsky, L., Bull, S.W., Holden, P., and Ireland, T.R. 2016. Trace element content of pyrite from the Kapai Slate, St. Ives gold district, Western Australia. Economic Geology, 111, pp. 1297-1320. https://doi.org/10.2113/ 
econgeo.111.6.1297

Grimm, K.A., Lange, C.B., and Gill, A.S. 1997. Self-sedimentation of phytoplankton blooms in the geologic record. Sedimentary Geology, 110, pp. 151-161. https://doi. org/10.1016/S0037-0738(97)00048-1

Guidotti, C.V. 1974. Transition from staurolite to sillimanite zone, Rangeley quadrangle, Maine. Geological Society of America Bulletin, 85, pp. 475-490. https://doi.org/10.113 0/0016-7606(1974)85<475:TFSTSZ>2.0.CO;2

Guidotti, C.V. and Holdaway, M.J. 1993. Petrology and field relations of successive metamorphic events in pelites of west-central Maine: evidence for equilibrium assemblages. In Field trip guidebook for the northeastern United States. Edited by J.T. Cheney and J.C. Hepburn. Amherst, Massachusetts, University of Massachusetts, Department of Geology and Geography Contribution 67, pp. L1-L26.

Guidotti, C.V. and Johnson, S.E. 2002. Pseudomorphs and associated microstructures of western Maine, USA. Journal of Structural Geology, 24, pp. 1139-1156. https://doi. org/10.1016/S0191-8141(01)00097-9

Guidotti, C.V. and Van Baalen, M.R. 2001. Geological, geochemical, and environmental aspects of metamorphosed black shales in central Maine. In Guidebook for geological field trips in New England. Edited by D.P. West and R.H. Bailey. Boulder, Colorado, Geological Society of America, Trip 6, pp. F1-F26.

Guidotti, C.V., Cheney, J.T., and Henry, D.J. 1977. Sulfide-silicate phase relations in metapelites of northwestern Maine. Transactions of the American Geophysical Union, 58, p. 524.

Guidotti, C.V., Cheney, J.T., Foster, C.T., Hames, W.E., Henry, D.J., Kinner, D.A., and Lux, D.R. 1996. Polymetamorphism in western Maine: mineralogic, petrologic and textural manifestations and regional geologic implications. In Guidebook to field trips in northern New Hampshire and adjacent regions of Maine and Vermont. Edited by M.R. Van Baalen. New England Intercollegiate Geological Conference, 88th Annual Meeting, Mount Washington, New Hampshire, pp. 171-202.

Hannigan, R.E. and Basu, A. 1998. Late diagenetic trace element remobilization in organic-rich black shales of the Taconic foreland basin of Québec, Ontario and New York. In Shales and mudstones. Edited by J. Schieber, W. Zimmerle, and P.S. Sethi. Stuttgart, Germany, E. Schweizerbart'sche Verlagsbuchhandlung, II, pp. 209-233.

Henry, D.J. 1981. Sulfide-silicate relations of the staurolite grade pelitic schists, Rangeley quadrangle, Maine. Unpublished Ph.D. thesis, University of Wisconsin, Madison, Wisconsin, $437 \mathrm{p}$.

Hirst, D.M. 1974. Geochemistry of sediments from eleven Black Sea cores. In The Black Sea-geology, chemistry, and biology. Edited by E.T. Degens and D.A. Ross. American Association of Petroleum Geologists Memoir 20, pp. 430455.

Holdaway, M.J., Guidotti, C.V., Novak, J.M., and Henry, W.E. 1982. Polymetamorphism in medium- to high-grade pelitic metamorphic rocks, west-central Maine. Geological
Society of America Bulletin, 93, pp. 572-584. https:// doi.org/10.1130/0016-7606(1982)93<572:PIMTHP>2.0. $\mathrm{CO} ; 2$

Hurtgen, M.T., Lyons, T.W., Ingall, E.D., and Cruse, A.M. 1999. Anomalous enrichments of iron monosulfide in euxinic marine sediments and the role of $\mathrm{H}_{2} \mathrm{~S}$ in iron sulfide transformations: examples from Effingham Inlet, Orca Basin, and the Black Sea. American Journal of Science, 299, pp. 556-588. https://doi.org/10.2475/ajs.299.7-9.556

Johnson, S.C., Large, R.R., Coveney, R.M., Kelley, K.D., Slack, J.F., Steadman, J.A., Gregory, D.D., Sack, P.J., and Meffre, S. 2017. Secular distribution of highly metalliferous black shales corresponds with peaks in past atmosphere oxygenation. Mineralium Deposita, 52, pp. 791798. https://doi.org/10.1007/s00126-017-0735-7

Jones, B. and Manning, D.A.C. 1994. Comparison of geochemical indices used for the interpretation of palaeoredox conditions in ancient mudstones. Chemical Geology, 111, pp. 111-129. https://doi.org/10.1016/00092541(94)90085-X

Ketris, M.P. and Yudovich, Ya.E. 2009. Estimates of Clarkes for carbonaceous biolithes: world averages for trace element contents in black shales and coals. International Journal of Coal Geology, 78, pp. 135-148. https://doi. org/10.1016/j.coal.2009.01.002

Kramer, C.Y. 1956. Extension of multiple range tests to group means with unequal numbers of replications. Biometrics, 12, pp. 307-310. https://doi.org/10.2307/3001469

Kříbek, B., Sýkorová, I., Machovič, V., and Laufek, F. 2008. Graphitization of organic matter and fluid-deposited graphite in Palaeoproterozoic (Birimian) black shales of the Kaya-Goren greenstone belt (Burkina Faso, West Africa). Journal of Metamorphic Petrology, 26, pp. 937-958. https://doi.org/10.1111/j.1525-1314.2008.00796.x

Land, L.S., Mack, L.E., Milliken, K.L., and Lynch, F.L. 1997. Burial diagenesis of argillaceous sediment, south Texas Gulf of Mexico sedimentary basin: a reexamination. Geological Society of America Bulletin, 109, pp. 2-15. https://doi.org/10.1130/0016-7606(1997)109<0002:BDOASS $>2.3 . \mathrm{CO} ; 2$

Large, R.R., Maslennikov, V.V., Robert, F., Danyushevsky, L.V., and Chang, Z. 2007. Multistage sedimentary and metamorphic origin of pyrite and gold in the giant Sukhoi Log deposit, Lena gold province, Russia. Economic Geology, 102, pp. 1233-1267. https://doi.org/10.2113/ gsecongeo.102.7.1233

Large, R.R., Bull, S.W., and Maslennikov, V.V. 2011. A carbonaceous sedimentary source-rock model for Carlin-type and orogenic gold deposits. Economic Geology, 106, pp. 331-358. https://doi.org/10.2113/econgeo.106.3.331

Leslie, B.W., Hammond, D.E., Berelson, W.M., and Lund, S.P. 1990. Diagenesis in anoxic sediments from the California continental borderland and its influence on iron, sulfur, and magnetite behavior. Journal of Geophysical Research, 95(B4), pp. 4453-4470. https://doi.org/10.1029/ JB095iB04p04453

Lev, S.M. and Filer, J.K. 2004. Assessing the impact of black 
shale processes on REE and the $\mathrm{U}-\mathrm{Pb}$ isotope system in the southern Appalachian Basin. Chemical Geology, 206, pp. 393-406. https://doi.org/10.1016/j.chemgeo.2003.12.012

Lev, S.M., McLennan, S.M., and Hanson, G.N. 1999. Mineralogic controls on REE mobility during black shale diagenesis. Journal of Sedimentary Research, 69, pp. 10711082. https://doi.org/10.2110/jsr.69.1071

Lev, S.M., Filer, J.K., and Tomascak, P. 2008. Orogenesis vs. diagenesis: can we use organic-rich shales to interpret the tectonic evolution of a depositional basin? Earth-Science Reviews, 86, pp. 1-14. https://doi.org/10.1016/j.earscirev.2007.07.001

Lewan, M.D. 1984. Factors controlling the proportionality of vanadium to nickel in crude oils. Geochimica et Cosmochimica Acta, 48, pp. 2231-2238. https://doi. org/10.1016/0016-7037(84)90219-9

Li, Y.-H. and Schoonmaker, J.E. 2003. Chemical composition and mineralogy of marine sediments. In Sediments, diagenesis, and sedimentary rocks. Edited by F.T. Mackenzie. Amsterdam, Elsevier, Treatise on Geochemistry, 7, pp. 1-35. https://doi.org/10.1016/B0-08-043751-6/07088-2

Losh, S. and Rague, R. 2018. Hydrothermal oxidation in the Biwabik Iron Formation, MN, USA. Mineralium Deposita, 53, pp. 1143-1166. https://doi.org/10.1007/s00126017-0783-Z

Ludman, A. 1977. Geologic map and cross sections of the Skowhegan 15' quadrangle, Maine. Maine Geological Survey Map GM-5, scale 1:62 500, includes 25 p. pamphlet.

Ludman, A., Hopeck, J., and Berry, H.N. IV. 2017. Provenance and paleogeography of post-Middle Ordovician, pre-Devonian sedimentary basins on the Gander composite terrane, eastern and east-central Maine: implications for Silurian tectonics in the northern Appalachians. Atlantic Geology, 53, pp. 63-85. https://doi.org/10.4138/ atlgeol.2017.003

Ludman, A., Machado, G., and Fernandes, P. 2020. Palynological dating of low-grade metamorphosed rocks: applications to early Paleozoic rocks of the Central Maine/ Aroostook-Matapedia Basin and Fredericton Trough (northern Appalachians) in eastern and east-central Maine, U.S.A. American Journal of Science, 320, pp. 280 312. https://doi.org/10.2475/03.2020.03

Lyons, T.W. and Berner, R.A. 1992. Carbon-sulfur-iron systematics of the uppermost deep-water sediments of the Black Sea. Chemical Geology, 99, pp. 1-27. https://doi. org/10.1016/0009-2541(92)90028-4

Lyons, T.W., Werne, J.P., Hollander, D.J., and Murray, R.W. 2003. Contrasting sulfur geochemistry and $\mathrm{Fe} / \mathrm{Al}$ and $\mathrm{Mo} / \mathrm{Al}$ ratios across the last oxic-to-anoxic transition in the Cariaco Basin, Venezuela. Chemical Geology, 195, pp. 131-157. https://doi.org/10.1016/S0009-2541(02)00392$\underline{3}$

Lyubetskaya, T. and Ague, J.J. 2010. Modeling metamorphism in collisional orogens intruded by magmas: II. Fluid flow and implications for Barrovian and Buchan metamorphism, Scotland. American Journal of Science, 310, pp. 459-491. https://doi.org/10.2475/06.2010.02

Macquaker, J.H.S., Keller, M.A., and Davies, S.A. 2010. Algal blooms and "marine snow": mechanisms that enhance preservation of organic carbon in ancient fine-grained sediments. Journal of Sedimentary Research, 80, pp. 934942. https://doi.org/10.2110/jsr.2010.085

Marvinney, R.G., West, D.P., Jr., Grover, T.W., and Berry, H.N. IV. 2010. A stratigraphic review of the Vassalboro Group in a portion of central Maine. In Guidebook for field trips in coastal and interior Maine. Edited by C. Gerbi, M. Yates, A. Kelley, and D. Lux. New England Intercollegiate Geological Conference, 102nd Annual Meeting, Orono, Maine, Field Trip Guidebook, pp. A5-1-A5-16.

Masters, R.L. and Ague, J.J. 2005. Regional-scale fluid flow and element mobility in Barrow's metamorphic zones, Stonehaven, Scotland. Contributions to Mineralogy and Petrology, 150, pp. 1-18. https://doi.org/10.1007/s00410005-0005-Z

McLennan, S.M., Hemming, S., McDaniel, D.K., and Hanson, G.N. 1993. Geochemical approaches to sedimentation, provenance, and tectonics. In Processes controlling the composition of clastic sediments. Edited by M.J. Johnsson and A. Basu. Geological Society of America Special Paper 284, pp. 21-40. https://doi.org/10.1130/ SPE284-p21

Merriman, R.J., Breward, N., Stone, P., Green, K., and Kemp, S. 2009. Element mobility and low-grade metamorphism of mudrocks in British Caledonian basins. British Geological Survey Internal Report OR/09/017, 28 p.

Milliken, K.L. 2003. Late diagenesis and mass transfer in sandstone-shale sequences. In Sediments, diagenesis, and sedimentary rocks. Edited by F.T. Mackenzie. Amsterdam, Elsevier, Treatise on Geochemistry, 7, pp. 159-190. https://doi.org/10.1016/B0-08-043751-6/07091-2

Moench, R.H. 2006. Stratigraphy of the central Maine trough from Oquossoc to Rangeley and Phillips, Maine. In Guidebook for field trips in western Maine. Edited by D. Gibson, J. Daly, and D. Reusch. New England Intercollegiate Geological Conference, $98^{\text {th }}$ Annual Meeting, Rangeley, Maine, pp. 77-88.

Moench, R.H. and Pankiwskyj, K.A. 1988. Geologic map of western interior Maine. U.S. Geological Survey Miscellaneous Investigations Series Map I-1692, scale 1:250 000.

Moench, R.H., Boone, G.M., Bothner, W.A., Boudette, E.L., Hatch, N.L. Jr., Hussey, A.M. II, Marvinney, R.G., and Aleinikoff, J.N. 1995. Geologic map of the Sherbrook-Lewiston area, Maine, New Hampshire, and Vermont, United States, and Québec, Canada. U.S. Geological Survey Map I-1898-D, 56 p., scale 1:250 000, 2 sheets.

Nishimura, Y., Coombs, D.S., Landis, C.A., and Itaya, T. 2000. Continuous metamorphic gradient documented by graphitization and K-Ar age, southeast Otago, New Zealand. American Mineralogist, 85, pp. 1625-1636. https:// doi.org/10.2138/am-2000-11-1206

Osberg, P.H., Hussey, A.M. II, and Boone, G.M. 1985. Bedrock geologic map of Maine. Augusta, Maine, Maine Geological Survey, scale 1:500 000. 
Pitcairn, I.K., Olivo, G.R., Teagle, D.A.H., and Craw, D. 2010a. Sulfide evolution during prograde metamorphism of the Otago and Alpine schists, New Zealand. The Canadian Mineralogist, 48, pp. 1267-1295. https://doi. org/10.3749/canmin.48.5.1267

Pitcairn, I.K., Skelton, A.D.L., Broman, C., Arghe, F., and Boyce, A. 2010b. Structurally focused fluid flow during orogenesis: the Islay anticline, SW Highlands, Scotland. Journal of the Geological Society, 167, pp. 659-674. https://doi.org/10.1144/0016-76492009-135

Pitcairn, I.K., Skelton, A.D.L., and Wohlgemuth-Ueberwasser, C.C. 2015. Mobility of gold during metamorphism of the Dalradian. Lithos, 233, pp. 69-88. https://doi. org/10.1016/j.lithos.2015.05.006

Quinby-Hunt, M.S. and Wilde, P. 1994. Thermodynamic zonation in the black shale facies based on iron-manganese-vanadium content. Chemical Geology, 113, pp. 297-317. https://doi.org/10.1016/0009-2541(94)90072-8

Raiswell, R. and Berner, R.A. 1985. Pyrite formation in euxinic and semi-euxinic sediments. American Journal of Science, 285, pp. 710-724. https://doi.org/10.2475/ ajs.285.8.710

Raiswell, R. and Berner, R.A. 1986. Pyrite and organic matter in Phanerozoic normal marine shales. Geochimica et Cosmochimica Acta, 50, pp. 1967-1976. https://doi. org/10.1016/0016-7037(86)90252-8

Raiswell, R. and Berner, R.A. 1987. Organic carbon losses during burial and thermal maturation of normal marine shales. Geology, 15, pp. 853-856. https://doi. org/10.1130/0091-7613(1987)15<853: OCLDBA>2.0. $\underline{\mathrm{CO} ; 2}$

Reusch, D.N. and van Staal, C.R. 2012. The Dog Bay-Liberty line and its significance for Silurian tectonics of the northern Appalachian orogen. Canadian Journal of Earth Sciences, 49, pp. 239-258. https://doi.org/10.1139/e11$\underline{024}$

Richter, D.A. and Roy, D.C. 1974. Sub-greenschist metamorphic assemblages in northern Maine. The Canadian Mineralogist, 12, pp. 469-474.

Ripley, E.M., Shaffer, N.R., and Gilstrap, M.S. 1990. Distribution and geochemical characteristics of metal enrichment in the New Albany Shale (Devonian-Mississippian), Indiana. Economic Geology, 85, pp. 1790-1807. https:// doi.org/10.2113/gsecongeo.85.8.1790

Rimmer, S.M. 2004. Geochemical paleoredox indicators in the Devonian-Mississippian black shales, central Appalachian Basin (USA). Chemical Geology, 206, pp. 373-391. https://doi.org/10.1016/j.chemgeo.2003.12.029

Roy, D.C. 1981. Reconnaissance bedrock geology of the Sherman, Mattawamkeag, and Millinocket 15' quadrangles, Maine. Maine Geological Survey Open-File Report 81-46, 18 p.

Roy, D.C, Demarest, N.A., and Hill, M.J. 1983. Stratigraphy and sedimentation in Silurian flysch east of Millinocket, Maine. In The Greenville-Millinocket regions, north-central Maine. Edited by D.W. Caldwell and L.S. Hanson. New England Intercollegiate Geological Conference
Guidebook, $75^{\text {th }}$ Annual Meeting, pp. 123-145.

Sageman, B.B. and Lyons, T.W. 2003. Geochemistry of finegrained sediments and sedimentary rocks. In Sediments, diagenesis, and sedimentary rocks. Edited by F.T. Mackenzie. Amsterdam, Elsevier, Treatise on Geochemistry, 7, pp. 115-158. https://doi.org/10.1016/B0-08-0437516/07157-7

Sanford, R.F., Pierson, C.T., and Crovelli, R.A. 1993. An objective replacement method for censored geochemical data. Mathematical Geology, 25, pp. 59-80. https://doi. org $/ 10.1007 / \mathrm{BF} 00890676$

SAS Institute Inc. 2018. JMP software, v. 14.3.0. Available at: www.sas.com

Scott, C. and Lyons, T.W. 2012. Contrasting molybdenum cycling and isotopic properties in euxinic versus non-euxinic sediments and sedimentary rocks: refining the paleoproxies. Chemical Geology, 324-325, pp. 19-27. https://doi.org/10.1016/j.chemgeo.2012.05.012

Scott, C., Jarboe, P., Slack, J.F., and Kelley, K.D. 2017a. The influence of thermal maturation on trace metal/total organic carbon ratios in black shales of the Bakken Formation. Goldschmidt 2017 Conference, August 13-18, 2017, Paris, France, Abstracts Volume.

Scott, C., Slack, J.F., and Kelley, K.D. 2017b. The hyper-enrichment of $\mathrm{V}$ and $\mathrm{Zn}$ in black shales of the Late Devonian-Early Mississippian Bakken Formation (USA). Chemical Geology, 452, pp. 24-33. https://doi.org/10.1016/j. chemgeo.2017.01.026

Skei, J. 1983. Geochemical and sedimentological considerations of a permanently anoxic fjord-Framvaren, south Norway. Sedimentary Geology, 36, pp. 131-145. https:// doi.org/10.1016/0037-0738(83)90006-4

Skelton, A.D.L., Graham, C.M., and Bickle, M.J. 1995. Lithological and structural controls on regional 3-D fluid flow patterns during greenschist facies metamorphism of the Dalradian of the SW Scottish Highlands. Journal of Petrology, 36, pp. 563-586. https://doi.org/10.1093/petrology/36.2.563

Slack, J.F., Selby, D., and Dumoulin, J.A. 2015. Hydrothermal, biogenic, and seawater components in metalliferous black shales of the Brooks Range, northern Alaska: synsedimentary metal enrichment in a carbonate ramp setting. Economic Geology, 110, pp. 653-675. https://doi. org/10.2113/econgeo.110.3.653

Taylor, S.R. and McLennan, S.M. 1985. The continental crust: its composition and evolution. Blackwell Scientific Publications, Oxford, U.K., 312 p.

Tomkins, A.G. 2010. Windows of metamorphic sulphur liberation in the crust: implications for gold deposit genesis. Geochimica et Cosmochimica Acta, 74, pp. 3246-3259. https://doi.org/10.1016/j.gca.2010.03.003

Tremblay, A., Hébert, R., and Bergeron, M. 1989. Le Complexe d'Ascot des Appalaches du sud du Québec: pétrologie et géochimie. Canadian Journal of Earth Sciences, 26, pp. 2407-2420. https://doi.org/10.1139/e89-206

Tribovillard, N., Algeo, T.J., Lyons, T., and Riboulleau, A. 2006. Trace metals as paleoredox and paleoproductivity 
proxies: an update. Chemical Geology, 232, pp. 12-32. https://doi.org/10.1016/j.chemgeo.2006.02.012

Van Baalen, M.R. 2006. Geology and geochemistry of metamorphosed black shales in central Maine. In Guidebook for field trips in western Maine. Edited by D. Gibson, J. Daly, and D. Reusch. New England Intercollegiate Geological Conference, $98^{\text {th }}$ Annual Meeting, Rangeley, Maine, pp. 217-238.

Van Baalen, M.R., Guidotti, C.V., Mingram, B., and Harlov, D.E. 2005. Reading the record: mineral and whole-rock geochemistry in sulfidic, graphitic schists as indicators of black shale depositional environments. Geological Society of America Abstracts with Programs, 37(7), p. 184.

Van Baalen, M., Reusch, D.N., and Slack, J.F. 2017. Smalls Falls revisited: a journey through a Paleozoic sedimentary basin. In Guidebook for field trips in western Maine and northern New Hampshire. Edited by B. Johnson and J.D. Eusden. New England Intercollegiate Geological Conference, $109^{\text {th }}$ Annual Meeting, Bethel, Maine, pp. A2-1-A226. https://doi.org/10.26780/2017.001.0003

Ventura, G.T., Gall, L., Siebert, C., Prytulak, J., Szatmari, P., Hürlimann, M., and Halliday, A.N. 2015. The stable isotope composition of vanadium, nickel, and molybdenum in crude oils. Applied Geochemistry, 59, pp. 104-117. https://doi.org/10.1016/j.apgeochem.2015.04.009

Wang, D., Aller, R.C., and Sañudo-Wilhelmy, S.A. 2011. Redox speciation and early diagenetic behavior of dissolved molybdenum in sulfidic muds. Marine Chemistry, 125, pp. 101-107. https://doi.org/10.1016/j.marchem.2011.03.002

Wang, G.-F. 1989. Carbonaceous material in the Ryoke metamorphic rocks, Kinki district, Japan. Lithos, 22, pp. 305-316. https://doi.org/10.1016/0024-4937(89)90032-7

Wignall, P.B. 1994. Black shales. Oxford, U.K., Clarendon Press, Oxford Monographs on Geology, 30, 27 p.
Wignall, P.B. and Newton, R. 1998. Pyrite framboid diameter as a measure of oxygen deficiency in ancient mudrocks. American Journal of Science, 298, pp. 537-552. https://doi.org/10.2475/ajs.298.7.537

Wilkin, R.T., Arthur, M.A., and Dean, W.E. 1997. History of water-column anoxia in the Black Sea indicated by pyrite framboid size distributions. Earth and Planetary Science Letters, 148, pp. 517-525. https://doi.org/10.1016/S0012$\underline{821 X(97) 00053-8}$

Wintsch, R.P., O'Connell, A.F., Ransom, B.L., and Wiechmann, M.J. 1981. Evidence for the influence of $\mathrm{f}_{\mathrm{CH} 4}$ on the crystallinity of disseminated carbon in greenschist facies rocks, Rhode Island, USA. Contributions to Mineralogy and Petrology, 77, pp. 207-213. https:// doi. org/10.1007/BF00373536

Yang, T., Cao, Y., Friis, H., Wang, Y., and Zhou, L. 2018a. Diagenetic evolution and chemical changes of deep-water mudstones of Shahejie Formation in the Dongying sag, Jiyang depression, eastern China. Marine and Petroleum Geology, 93, pp. 14-32. https://doi.org/10.1016/j.marpetgeo.2018.02.005

Yang, W., Gao, Y., and Casey, J.F. 2018b. Determination of trace elements in crude oils and fuel oils: a comprehensive review and new data. In Solution chemistry: advances in research and applications. Edited by Y. Xiong. Hauppauge, New York, Nova Science Publishers, pp. 159-205.

Editorial responsibility: David P. West, Jr.

\section{APPENDIX}

Appendix Tables A1 and A2 on following pages. 


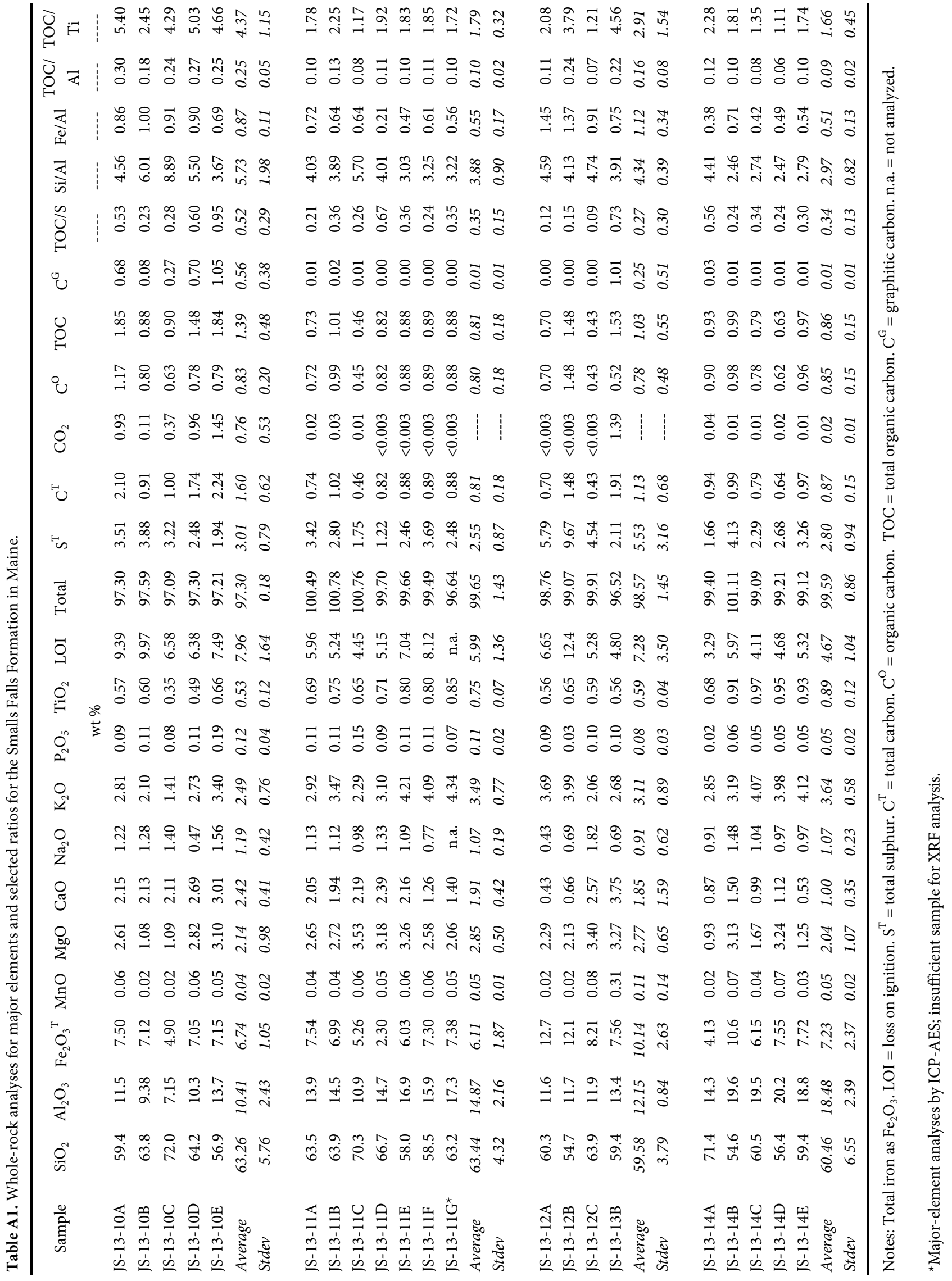




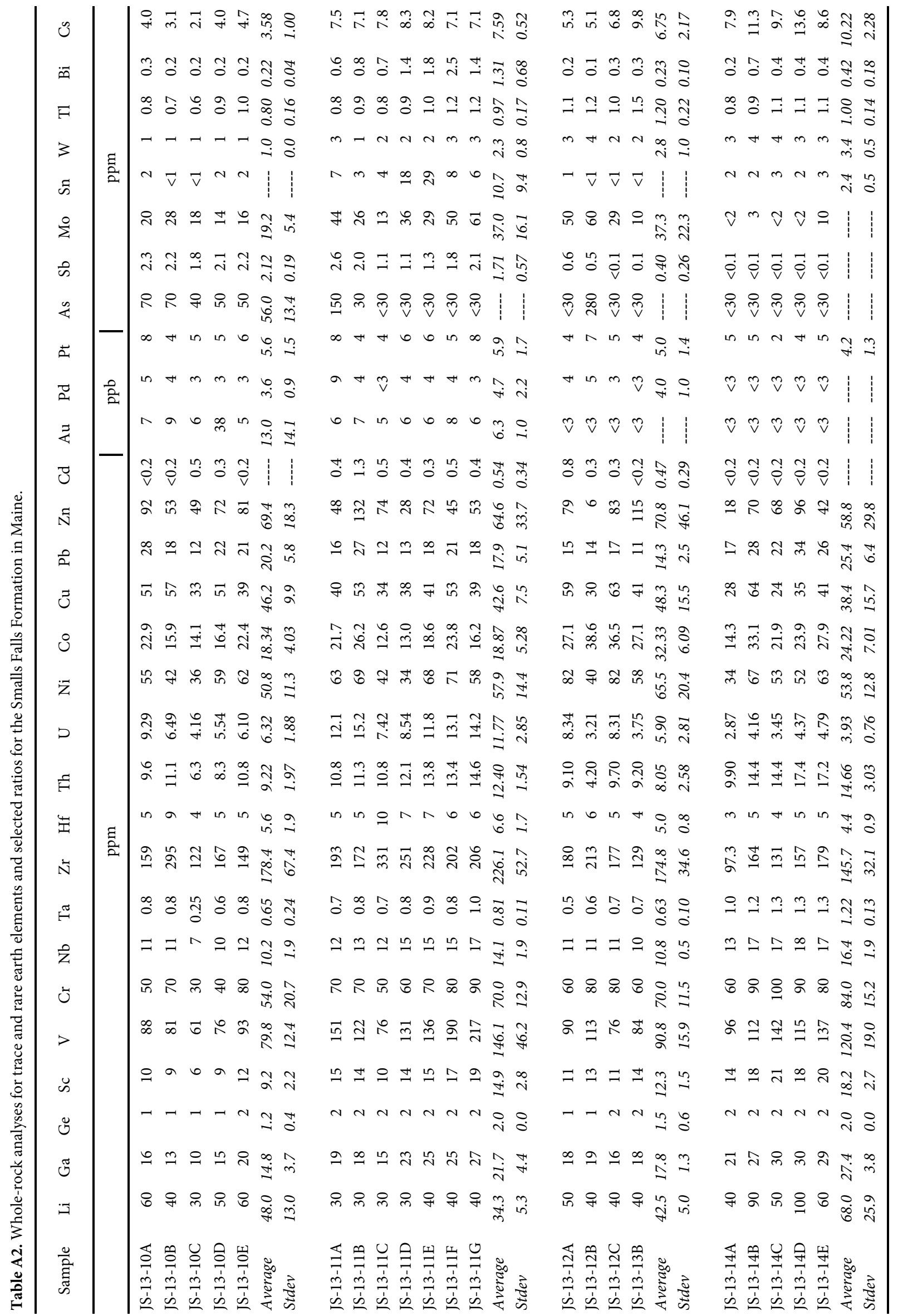




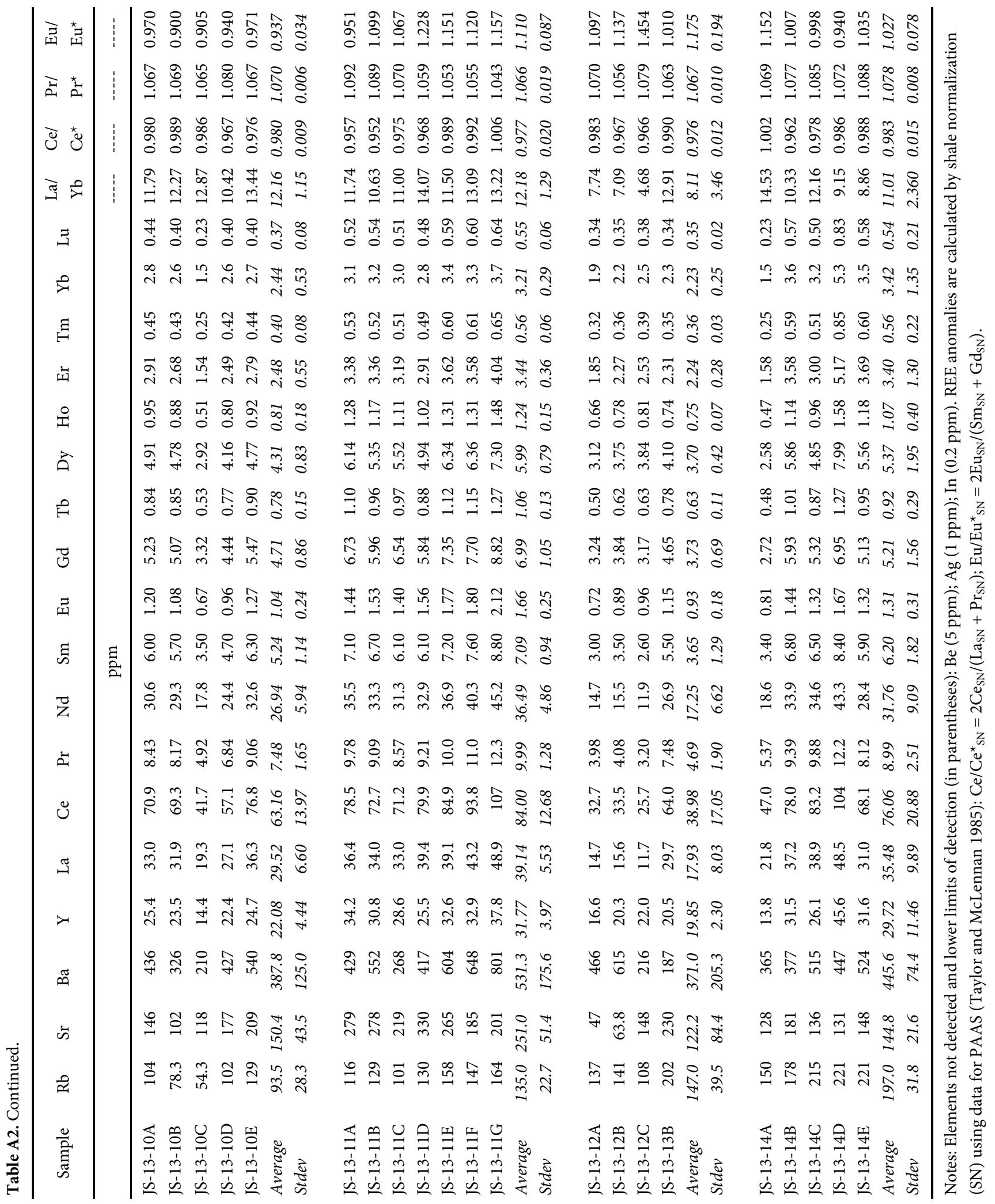

